\title{
A new Late Agenian (MN2a, Early Miocene) fossil assemblage from Wallenried (Molasse Basin, Canton Fribourg, Switzerland)
}

\author{
Bastien Mennecart ${ }^{1,2,3}$, Bertrand Yerly ${ }^{1,4}$, Pierre-Olivier Mojon ${ }^{5}$, Chiara Angelone ${ }^{6}$, Olivier Maridet ${ }^{2,7}$ \\ Madelaine Böhme ${ }^{8,9}$, Claudius Pirkenseer ${ }^{1,2,10}$
}

\begin{abstract}
Excavations of two fossiliferous layers in the Wallenried sand- and marl pit produced a very diversified vertebrate fauna. New material allows the reassessment of the taxonomic position of the ruminant taxa Andegameryx andegaviensis and endemic Friburgomeryx wallenriedensis. An emended diagnosis for the second species is provided and additional material of large and small mammals, as well as ectothermic vertebrates, is described. The recorded Lagomorpha show interesting morphological deviations from other Central European material, and probably represent a unique transitional assemblage with a co-occurrence of Titanomys, Lagopsis and Prolagus. Rodentia and Eulipotyphla belong to typical and well-known species of the Agenian of the Swiss Molasse Basin. Abundant small mammal teeth have allowed
\end{abstract}

\author{
Claudius Pirkenseer \\ claudiusmarius.pirkenseer@unifr.ch \\ Bastien Mennecart \\ mennecartbastien@gmail.com \\ Bertrand Yerly \\ bertrand.yerly@gmail.com \\ Pierre-Olivier Mojon \\ pierreoliviermojon@bluewin.ch \\ Chiara Angelone \\ chiara.angelone@icp.cat \\ Olivier Maridet \\ olivier.maridet@jurassica.ch \\ Madelaine Böhme \\ m.boehme@ifg.uni-tuebingen.de
}

1 Natural History Museum of Fribourg, Chemin du Musée 6, Pérolles, 1700 Fribourg, Switzerland

2 Department of Geosciences, Earth Sciences, University of Fribourg, Chemin du Musée 6, Pérolles, 1700 Fribourg, Switzerland us to pinpoint the biostratigraphic age of Wallenried to late MN2a. The biostratigraphic age conforms to data derived from the charophyte assemblages and confirms the oldest occurrence of venomous snake fangs. The palaeoenvironmental context is quite complex. Sedimentary structures and fauna (fishes, frogs, salamanders, ostracods) are characteristic for a humid, lacustrine environment within a flood plain system.

Keywords Biostratigraphy · Palaeoenvironment . Mammalia $\cdot$ Reptilia $\cdot$ Ostracoda $\cdot$ Charophyta

Kurzfassung Grabungen in fossilreichen Schichten der Sandgrube Wallenried ergaben eine artenreiche Wirbeltierfauna. Neues Material ermöglicht die Evaluation des

3 CR2P-Centre de Recherches sur la Paléobiodiversité et les Paléoenvironnements, UMR 7207, Muséum National d'Histoire Naturelle, CNRS, UPMC, Sorbonne Universités, MNHN, CP38, 8 rue Buffon, 75005 Paris, France

4 Laboratoire Romand de Dendrochronologie, rue Saint-Michel 4, CP 161, 1510 Moudon, Switzerland

5 Rue du Centre 81, 2405 La Chaux-du Milieu, Switzerland

6 Institut Català de Paleontologia, Edifici Z, c/de les Columnes s/n, Campus de la UAB-E-08193 Cerdanyola del Vallès, Barcelona, Spain

7 Jurassica Museum, route de Fontenais 21, 2900 Porrentruy, Switzerland

8 Eberhard Karls University, Sigwartstraße 10, 72076 Tübingen, Germany

9 Senckenberg Center for Human Evolution and Palaeoenvironment (HEP Tübingen), Tübingen, Germany

10 Paléontologie A16, Office de la Culture, Canton du Jura, Rue de la Chaumont 13, 2900 Porrentruy, Switzerland 
taxonomischen Status der Ruminantia Andegameryx andegaviensis und dem endemischen Friburgomeryx wallenriedensis, mit einer ergänzenden Diagnose der letzteren Art. Zusätzliches Material von Säugetieren und ektothermen Wirbeltieren wird beschrieben. Die erfassten Lagomorpha weisen gegenüber anderem zentraleuropäischen Material interessante morphologische Abweichungen auf. Sie stellen wegen des gleichzeitigen Auftretens von Titanomys, Lagopsis und Prolagus möglicherweise eine einzigartige Übergangsfauna dar. Rodentia and Eulipotyphla gehören typischen und bekannten Arten des Ageniums des Schweizer Molassebeckens an. Dank der zahlreichen Kleinsäugerzähne kann das biostratigraphische Alter der Sedimente von Wallenried auf MN2a eingegrenzt werden. Dieses Alter entspricht auch den Ergebnissen der Charophytenvergesellschaftung und bestätigt das älteste Vorkommen von Giftschlangenzähnen. Die Paläoumwelt war recht komplex. Sedimentstrukturen und Faunen (Fische, Salamander, Frösche, Ostrakoden) sind für ein feuchtes, lakustrines Milieu der Überflutungsflächen innerhalb der Flussauen eines mäandrierenden Flusses charakteristisch.

Schlüsselwörter Biostratigraphie - Paläoumwelt · Mammalia · Reptilia · Ostracoda $\cdot$ Charophyta

$\begin{array}{ll}\text { Abbreviations } \\ \mathrm{p} & \text { Lower premolar } \\ \mathrm{m} & \text { Lower molar } \\ \mathrm{C} & \text { Upper canine } \\ \mathrm{P} & \text { Upper premolar } \\ \mathrm{M} & \text { Upper molar } \\ \mathrm{d} & \text { Lower deciduous premolar } \\ \mathrm{D} & \text { Upper deciduous premolar } \\ \text { OMM } & \text { Obere Meeresmolasse (Upper Marine Molasse) } \\ \text { USM } & \text { Untere Süßwassermolasse (Lowe Freshwater } \\ & \text { Molasse) } \\ \text { MHNF } & \text { Natural History Museum of Fribourg (Musée } \\ & \text { d'histoire naturelle de Fribourg) }\end{array}$

\section{Introduction}

The sand and marl pit (574.45/192.45; WallA $46.88164 \mathrm{~N} /$ $7.10652 \mathrm{E}$; WallE 46.88084/7.10691 E) near the village Wallenried is located $10 \mathrm{~km}$ north of Fribourg, Switzerland (Fig. 1). The outcropping sediments form part of the "Molasse grise de Lausanne" Formation [Lower Freshwater Molasse (USM)] within the "Plateau Molasse" (Becker et al. 2001; Becker 2003) and are attributed to the Agenian European land mammal age. Several meters above the outcrop, typical Upper Marine Molasse (OMM) sandstones are observed. During the Agenian (Aquitanian-Burdigalian, Early Miocene), the sedimentation of the "Plateau Molasse" was controlled by Alpine
Fig. 1 a Location of the Wallenried fossiliferous localities, with new mammalian layers WallA and WallE indicated and simplified geology of the Swiss Molasse Basin [detail map modified from sheet 1185/98 (1996), Geological Atlas of Switzerland; overview map modified from Berger et al. (2005a)]. b Late Aquitanian (MN2a) palaeogeography of Switzerland and main sediment transport directions (modified from Berger et al. 2005b)

alluvial fans, the north-eastward directed drainage system of the "Genferseeschüttung", and the diachronous eastward transgression of the Upper Marine Molasse Sea occurring in the late Aquitanian and early Burdigalian (Berger et al. 2005b; Berger 2011; Becker et al. 2010).

The sedimentology and fossil assemblage of Wallenried was studied in detail by Becker (1996). According to Becker et al. (2001) the sedimentary architecture of the Wallenried quarry corresponds to a perennial meandering river system, with channel deposits and sandy bedforms dominated by medium to coarse sands and in decreasing granulometry from crevasse channel to floodplain deposits and/or oxbow lakes, with a predominance of fine-grained sediments. The mottled clayey to silty floodplain deposits relate to ephemeral ponds associated with seasonality in water supply. The richest fossil localities comprise the base of a channel fill ("channel"; Fig. 2) and fine-grained floodplain marls (e.g., WallA, WallE, W I.2, W III.1). At the moment, it is not possible to correlate the strata of the southern face (WallA, site of Becker et al. 2001) of the quarry with the northern face (WallE).

Mammal remains have been discovered in several layers (WI.1, WI.2, WIII.1, and Channel; Becker et al. 2001). The large mammal assemblages of layers WI.1, and WIII.1 are abundant and diverse. A fragmentary lower molar was referred to as from Andegameryx cf. laugnacensis, which is a relatively common species in Western Europe (Gentry et al. 1999; Ginsburg 1999; Becker et al. 2010). Most of the other ruminant remains have been attributed by Becker et al. (2001) to a new genus and species, Friburgomeryx wallenriedensis. Becker et al. (2001) also proposed a preliminary correlation to the biozone MN2b, based on the presence of the small mammal assemblage composed of Peridyromys murinus, Eucricetodon aff. gerandianus, and Prolagus praevasconiensis.

During a recent excavation campaign organized by the Natural History Museum of Fribourg, a well-preserved and diversified fauna was collected in the WallA level. A second highly fossiliferous level (WallE; Figs. 1, 2) yielded a different faunal assemblage, especially rich in small mammal fossils (more than 650 mandible and dental remains). In total, the material consists of ruminants, lagomorphs, rodents, insectivores, crocodiles, lizards, snakes, amphibians, fish, gastropods, ostracods, charophytes, and seeds. An updated faunal and floral list of the Agenian of Wallenried is summarized in Table 1.

In this work, we focus on mammal remains (in detail Cetartiodactyla and Lagomorpha), herpetofauna, Ostracoda, 


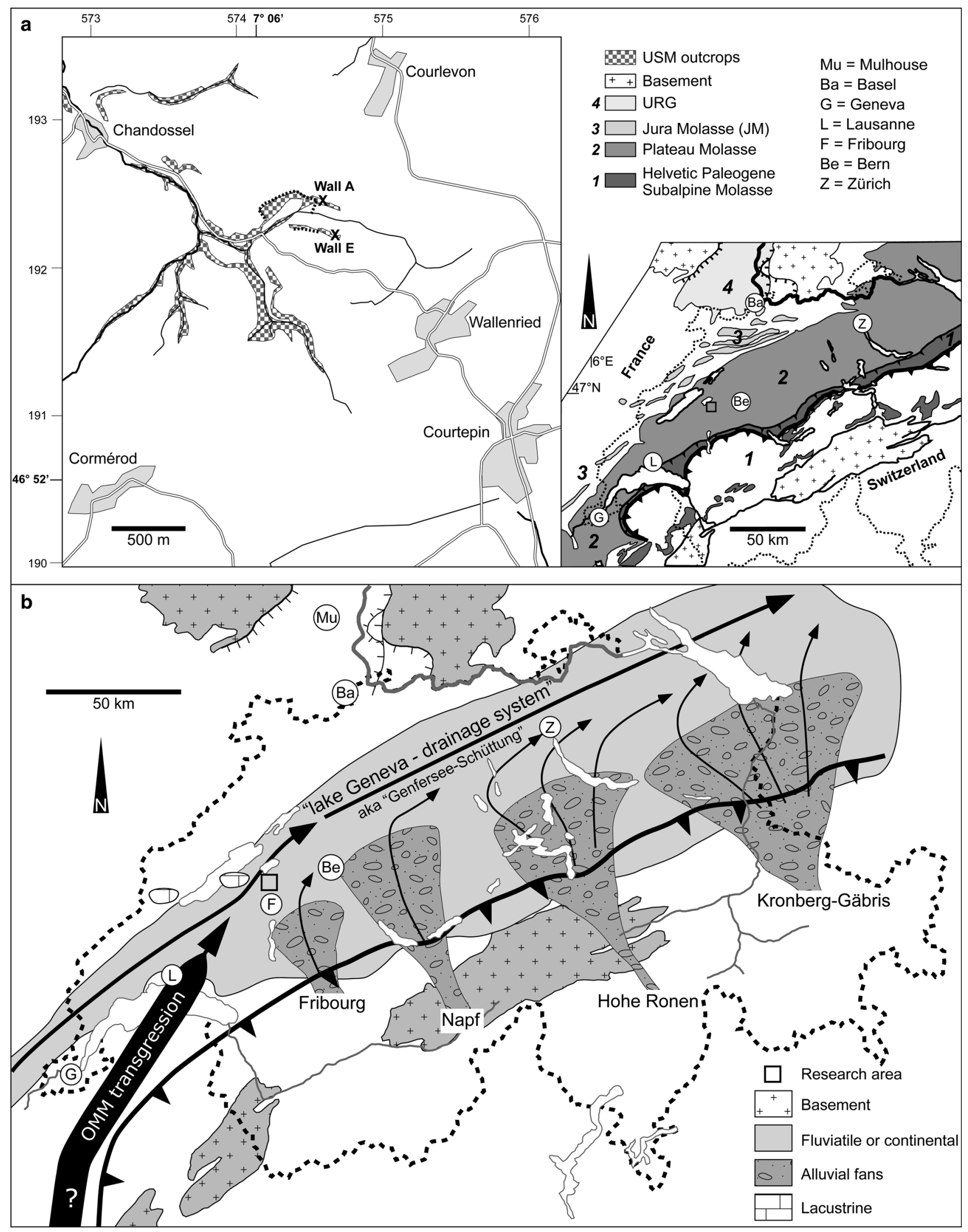




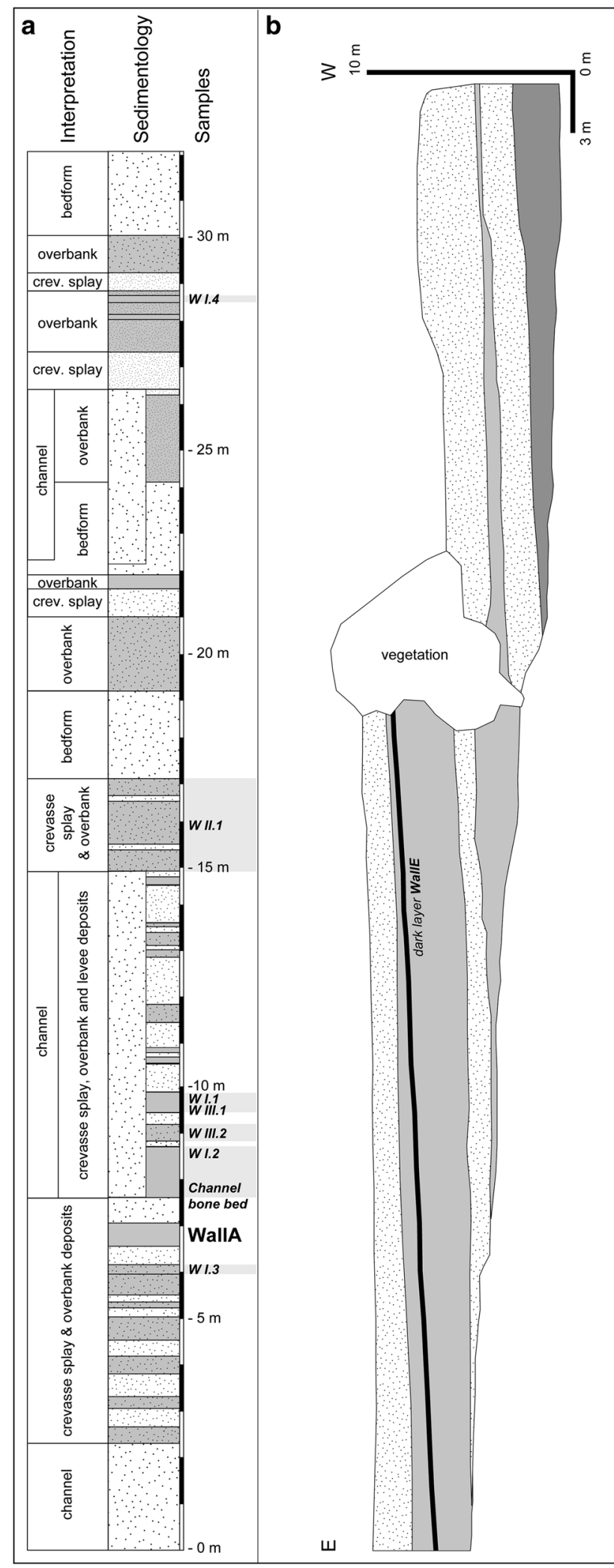

Fig. 2 a Simplified $\log$ of the Wallenried quarry north cliff and palaeoenvironmental interpretation (modified from Becker 2003). b Stratigraphic sketch of the Wallenried quarry south cliff (modified from Philipona 2011)
Charophyta and biostratigraphy derived from the new material. New biostratigraphical and palaeoenvironmental interpretations are provided, highlighting the importance of Wallenried among the Swiss Molasse Basin localities.

\section{Materials and methods}

\section{Palaeontology}

Approximately 1 ton of sediment was screen-washed down to $500-\mu \mathrm{m}$ mesh size. Identification is based on anatomical feature descriptions, comparative anatomy and biometrical measurements. The dental terminology follows Bärmann and Rössner (2011) for Ruminantia, adapted from Berthet (2003) for the Cainotheriidae. For Lagomorpha, the nomenclature and the measurements follow Angelone and Sesé (2009) for ochotonids, whereas they follow López Martínez (1989) for stem lagomorphs. All other Rodentia and Eulipotyphla are typical and well-known species of the Agenian of the Swiss Molasse Basin (Engesser and Mödden 1997). Thus, they are not described in detail in this article. The description of the herpetofauna, Charophyta and Ostracoda follows the cited literature. The ectothermic vertebrate fossils are very fragmented and in many cases, they can barely be determined to the family level; hence the limitation of the description to a general discussion.

All measurements are given with a precision of $0.1 \mathrm{~mm}$. The biochronological framework is based on chronological correlations of the European Land Mammal Zones (MNZones) (Mein 1999; Steininger 1999), the Swiss Reference Faunas (Engesser and Mödden 1997; Kempf et al. 1997), and the Paleogene and Neogene geological time scale (GTS 2012; Hilgen et al. 2012; Vandenberghe et al. 2012). The boundary MN2a/MN2b is used in this paper at the Swiss Molasse Basin scale (Engesser and Mödden 1997), although this subdivision of MN2 is no longer applied at the European biochronological scale due to a diachronic faunal turnover (Mein 1999). All referred specimens in this work are curated in the MHNF.

\section{Palaeontology}

Class MAMMALIA Linnaeus, 1758

Order CETARTIODACTYLA Montgelard, Catzeflis, and Douzery, 1997

Suborder RUMINANTIA Scopoli, 1777

Family INCERTAE SEDIS

Genus Andegameryx Ginsburg, 1971

Andegameryx andegaviensis Ginsburg, 1971

Fig. 3.1-2 
Table 1 Faunal and floral list of Wallenried fossiliferous layers (MN2a, Switzerland, Becker et al. 2001 and new data)

\begin{tabular}{|c|c|c|c|c|c|}
\hline & \multicolumn{3}{|c|}{ Becker et al. (2001) } & \multicolumn{2}{|c|}{ This paper } \\
\hline & $\mathrm{W} 1.2$ & W111.1 & Channel & WallA & Walle \\
\hline Fossil wood & $\mathrm{X}$ & $\mathrm{X}$ & & $X$ & $\mathrm{X}$ \\
\hline Charophyta & $X$ & & & $\mathrm{X}$ & $\mathrm{X}$ \\
\hline Stephanochara gr. praeberdotensis & & & & $\mathrm{X}$ & \\
\hline Stephanochara berdotensis & & & & $\mathrm{X}$ & \\
\hline Chara gr. notata & & & & $\mathrm{X}$ & \\
\hline Sphaerochara gr. hirmeri & & & & $\mathrm{X}$ & \\
\hline Gastropoda & $\mathrm{X}$ & $\mathrm{X}$ & & $\mathrm{X}$ & $\mathrm{X}$ \\
\hline Helicidae & $\mathrm{X}$ & $\mathrm{X}$ & $\mathrm{X}$ & $\mathrm{X}$ & $\mathrm{X}$ \\
\hline Limacidae & & $\mathrm{X}$ & $\mathrm{X}$ & $\mathrm{X}$ & $\mathrm{X}$ \\
\hline Ostracoda & & & & $\mathrm{X}$ & $\mathrm{X}$ \\
\hline Ilyocypris essertinesensis & & & & $\mathrm{X}$ & \\
\hline cf. Strandesia sp. A & & & & $\mathrm{X}$ & \\
\hline Psychrodromus aff. olivaceus & & & & & $\mathrm{X}$ \\
\hline cf. Moenocypris ingelheimensis & & & & $\mathrm{X}$ & \\
\hline Pseudocandona sp. & & & & $\mathrm{X}$ & \\
\hline Cypridopsinae indet. & & & & $\mathrm{X}$ & \\
\hline Vertebrata & $\mathrm{X}$ & $\mathrm{X}$ & $\mathrm{X}$ & $\mathrm{X}$ & $\mathrm{X}$ \\
\hline Cyprinidae & $\mathrm{X}$ & $\mathrm{X}$ & & $\mathrm{X}$ & $\mathrm{X}$ \\
\hline Fish vertebra & $\mathrm{X}$ & $\mathrm{X}$ & & $\mathrm{X}$ & \\
\hline Salamandridae indet. & & & & $\mathrm{X}$ & \\
\hline Anura indet. & & & & $\mathrm{X}$ & \\
\hline Lacertidae indet. & & & & $\mathrm{X}$ & \\
\hline Testudinata & & & $\mathrm{X}$ & & \\
\hline Ergilemys vel. Geochelone & & & $\mathrm{X}$ & & \\
\hline Ophisaurus & $\mathrm{X}$ & $\mathrm{X}$ & $\mathrm{X}$ & $\mathrm{X}$ & $\mathrm{X}$ \\
\hline Crocodilia & & $\mathrm{X}$ & $\mathrm{X}$ & & $\mathrm{X}$ \\
\hline Diplocynodon sp. & & & & $\mathrm{X}$ & \\
\hline Colubridae indet. & & & & $\mathrm{X}$ & \\
\hline Viperidae indet. & & & & $\mathrm{X}$ & \\
\hline Rodentia & $X$ & $\mathrm{X}$ & $\mathrm{X}$ & $\mathrm{X}$ & $\mathrm{X}$ \\
\hline Eomyidae & & $\mathrm{X}$ & $\mathrm{X}$ & $\mathrm{X}$ & $\mathrm{X}$ \\
\hline Ritteneria manca & & & & $X$ & \\
\hline Ritteneria molinae & & & & & $\mathrm{X}$ \\
\hline Pseudotheridomys aff. lacombai & & & & $\mathrm{X}$ & $\mathrm{X}$ \\
\hline Pseudotheridomys parvulus & & & & & $\mathrm{X}$ \\
\hline Gliridae & & $X$ & & $\mathrm{X}$ & $\mathrm{X}$ \\
\hline Peridyromys murinus & & $\mathrm{X}$ & & $\mathrm{X}$ & $\mathrm{X}$ \\
\hline Peridyromys sp. & & & & & $\mathrm{X}$ \\
\hline Bransatoglis cf. infractolensis ingens & & & & $\mathrm{X}$ & $\mathrm{X}$ \\
\hline Microdyromys legidensis & & & & & $\mathrm{X}$ \\
\hline Pseudodryomys cf. toriformis & & & & & $\mathrm{X}$ \\
\hline Cricetidae & $\mathrm{X}$ & $\mathrm{X}$ & $\mathrm{X}$ & $X$ & $\mathrm{X}$ \\
\hline Eucricetodon aff. gerandianus & $\mathrm{X}$ & & $\mathrm{X}$ & & \\
\hline Eucricetodon gerandianus & & & & $\mathrm{X}$ & $\mathrm{X}$ \\
\hline Eucricetodon haslachensis & & & & $X$ & \\
\hline
\end{tabular}


Table 1 continued

\begin{tabular}{|c|c|c|c|c|c|}
\hline & \multicolumn{3}{|c|}{ Becker et al. (2001) } & \multicolumn{2}{|c|}{ This paper } \\
\hline & $\mathrm{W} 1.2$ & W111.1 & Channel & WallA & WallE \\
\hline Lagomorpha & $X$ & $X$ & $\mathrm{X}$ & $X$ & $\mathrm{X}$ \\
\hline \multicolumn{6}{|l|}{ Ochotonidae } \\
\hline Prolagus sp. & & & & & $\mathrm{X}$ \\
\hline Prolagus aff. praevasconiensis & $X$ & $X$ & $\mathrm{X}$ & $X$ & \\
\hline Titanomys sp. & & & & $X$ & $X$ \\
\hline Lagopsis aff. spiracensis & & & & $X$ & \\
\hline \multicolumn{6}{|l|}{ Soricomorpha } \\
\hline Soricidae & & & & & $\mathrm{X}$ \\
\hline Clapasorex indet. & & & & & $X$ \\
\hline Soricella indet. & & & & & $X$ \\
\hline \multicolumn{6}{|l|}{ Talpidae } \\
\hline Paratalpa indet. & & & & & $\mathrm{X}$ \\
\hline Cetartiodactyla & $X$ & & $\mathrm{X}$ & $X$ & $X$ \\
\hline Andegameryx andegaviensis & $X$ & & $\mathrm{X}$ & & \\
\hline Friburgomeryx wallenriedensis & $X$ & & $\mathrm{X}$ & $X$ & \\
\hline Pecora indet. & & & & $\mathrm{X}$ & \\
\hline Cainotherium cf. gracile & & & & $X$ & \\
\hline
\end{tabular}

Referred specimens MHNF 28453, partial corpus mandibulae with $\mathrm{m} 2$ (first reported and figured in Becker et al. 2001 as Wr.3 "left m1", pl.1 Fig. 5); MHNF 31286, left mandible with m1-3; MHNF 31287, left D4.

\section{Description}

The measurements are summarized in Table 2 .

Lower adult dentition The molar crowns are brachyodont and relatively selenodont. The fossae are relatively narrow. The protoconid and the hypoconid are enlarged. The outline of these cuspids is relatively circular, with the postprotocristid and the posthypocristid transversally oriented. No external postprotocristid can be observed. The space between the postprotocristid and the prehypocristid is relatively large. The metaconid is relatively laterally compressed, whereas the entoconid is more globular. However, they remain relatively bulbous on their lingual face. The postentocristid is small but present. It closes the talonid. Even if it is broken on the studied specimens, we can observe that, contrary to the posterior cingulid, the anterior one is strong, forming a mesostylid. The metastylid and the entostylid are absent. The ectostylid is small.

Upper deciduous dentition D4 possesses selenodont and large cusps, a strong mesostyle, forming an enlarged small column, and a big parastyle oriented frontward. The metastyle forms a little spur at the end of the elongated postmetacristid. The trigonid is larger than the talonid due to a very narrow metaconule. The paracone and the metacone bear large ribs, with a small anterior groove on the paracone rib. The cingulum is weak on the anterior part of the tooth and seems absent on the posterior part. No neocrista obstructs the fossae.

\section{Discussion}

This medium-sized ruminant possesses relatively simple molars for a Pecora (bulged lingual cuspids and absence of metastylid). Such characteristics are also present in $\mathrm{Am}$ phitragulus and Friburgomeryx. However, the latter possesses an external postprotocristid on the lower molars (Becker et al. 2001, pers. obs.) that is weak to absent on those of Andegameryx (Ginsburg 1999). Moreover, the gap between the postentocristid and the posthypocristid is reduced in Andegameryx in comparison to the previous genera. D4 is similar to that of the specimen NMBE5014465 from Engehalde, identified as A. cf. laugnacensis by Becker et al. (2010). However, even if the material from Wallenried is a little larger than the hypodigm material of Andegameryx species, it should not belong to Friburgomeryx, due to a missing enlarged lingual cingulum, as is present in upper molars of Friburgomeryx.

Three different species of Andegameryx are currently defined. They are mainly based on size differences and biostratigraphic position (Ginsburg 1999). Andegameryx serum is the smallest and the youngest and A. laugnacensis 
Table 2 Dental measurements (in $\mathrm{mm}$ ) of Andegameryx andegaviensis and comparison with other species of this genus; in each row, the first datum is the length and the second is the width

\begin{tabular}{|c|c|c|c|c|c|c|c|c|c|}
\hline Locality & $\begin{array}{l}\text { Inventory } \\
\text { number }\end{array}$ & References & $\mathrm{pl}$ & $\mathrm{p} 2$ & p3 & $\mathrm{p} 4$ & $\mathrm{ml}$ & $\mathrm{m} 2$ & $\mathrm{~m} 3$ \\
\hline \multicolumn{10}{|l|}{ Andegameryx andegaviensis } \\
\hline \multirow[t]{2}{*}{ Wallenried (old locality) } & MHNF 28453 & Becker et al. (2001) & & & & & & $10.5 / 7.9$ & \\
\hline & MHNF 31286 & & & & & & $9.0 / 7.2$ & $10.9 / 8.0$ & $15.5 / 7.7$ \\
\hline Engehalde & NMBE-5016762 & Becker et al. (2010) & & & 8.8 & 9.2 & 9.5 & 10.6 & 16.1 \\
\hline La Brosse & Mean value & Ginsburg et al. (2000) & & 4.6 & $8.2 / 4.1$ & $9.2 / 5.7$ & $9.6 / 7.4$ & $10.3 / 7.5$ & $14.7 / 7.1$ \\
\hline Chiteney & Mean value & Ginsburg et al. (2000) & & & $8.6 / 4.9$ & $8.8 / 5.8$ & $9.4 / 7.4$ & $10.7 / 8.3$ & $15.5 / 7.9$ \\
\hline \multicolumn{10}{|l|}{ Andegameryx laugnacensis } \\
\hline Laugnac & Mean value & Ginsburg and Morales (1989) & $6.9 / 2.9$ & $8.87 / 4.4$ & $9.9 / 5.4$ & $10.4 / 6.7$ & $10.9 / 7.7$ & $12.0 / 8.9$ & $17.5 / 8.6$ \\
\hline \multicolumn{10}{|l|}{ Andegameryx sp. } \\
\hline La Encinilla & Mean value & Quiralte and Morales (2006) & & & $10.7 / 5.8$ & $11.0 / 6.6$ & $12.7 / 8.1$ & $14.8 / 10.6$ & $19.3 / 9.5$ \\
\hline Locality & Inventory number & References & D4 & & & & & & \\
\hline \multicolumn{10}{|l|}{ Andegameryx andegaviensis } \\
\hline Wallenried (old locality) & MHNF 31287 & & 11.9/10.9 & & & & & & \\
\hline Engehalde & NMBE-5014565 & Becker et al. (2010) & $10.8 / 9.9$ & & & & & & \\
\hline \multicolumn{10}{|l|}{ Andegameryx laugnacensis } \\
\hline Laugnac & Mean value & Ginsburg and Morales (1989) & $11.7 / 10.2$ & & & & & & \\
\hline
\end{tabular}

the largest and the oldest. Becker et al. (2001) erroneously described the unique specimen from Wallenried (WI.2 and channel; Becker et al. 2001, Fig. 5, MHNF 28453) as an $\mathrm{m} 1$ of Andegameryx cf. laugnacensis. The specimen, however, corresponds to an $\mathrm{m} 2$. Regarding the new discoveries, the descriptions, and the size comparisons (Table 2), the referred specimens clearly belong to $A$. andegaviensis. In light of this new identification, the specimens attributed to A. cf. laugnacensis in Engehalde (Becker et al. 2010) should also be considered as $A$. andegaviensis.

Genus Friburgomeryx Becker et al. 2001

Friburgomeryx wallenriedensis Becker et al. 2001

Fig. 3.3-6

Emended diagnosis Small to medium-sized ruminant with seleno-brachyodont dentition with more conical than crescent-shaped cusps. The upper molars possess a neocrista and strong parastyle, paracone, and mesostyle as well as a strong connected cingulum. The lower molars show a strong external postprotocristid and a rounded lingual wall of the metaconid. The lower premolars include p1. They are wide and bulky and poorly molarized. On p3, a short postprotocristid and posprotoconulidcristid are developed. p2 has a short postprotocristid and entocristid. The bunoselenodont lower molars bear an incomplete postentocristid and an enlarged mesostylid.
Referred specimens MHNF 28450 (Paratype), partial right maxilla with M1-3 weakly to strongly worn (old number Wr.1, figured in Becker et al. 2001, pl.1 Fig. 1); MHNF 28449 (Holotype), partial right maxilla with M1-3 moderately to strongly worn (old number Wr.2, figured in Becker et al. 2001, pl.1 Fig. 2); MHNF 31288 (Paratype), right corpus mandibulae with p1-m3 moderately to strongly worn (defined in Becker et al. 2001 as two different specimens Wr.4 and Wr.6, figured in Becker et al. 2001, as Wr.4 pl.1 Fig. 3); MHNF 31282 (Paratype), fragmentary left angular process and corpus with fragmentary $\mathrm{m} 3$ (old number Wr.5, first reported and figured in Becker et al. 2001 as "left m1, m2 or m3", pl.1 Fig. 4; however, the rest of the mandibular material labelled as turtle remains has been found); MHNF 28452, left mandible with m2-3; MHNF 31284, right nearly complete mandible with alveoli of the $\mathrm{d} 2$, the tooth row $\mathrm{d} 3-\mathrm{m} 1$, and $\mathrm{m} 2$ erupting; MHNF 31285, highly fragmented left mandible with badly preserved $\mathrm{d} 3, \mathrm{~d} 4, \mathrm{~m} 1$, and, $\mathrm{m} 2$; MHNF 28454, fragmented upper canine.

\section{Description}

The measurements are summarized in Table 3.

Mandible The corpus mandibulae are relatively massive. There is no diastema between $\mathrm{p} 1$ and $\mathrm{p} 2$. The height of the corpus becomes higher from $\mathrm{p} 1$ to $\mathrm{m} 3$. The incisura 

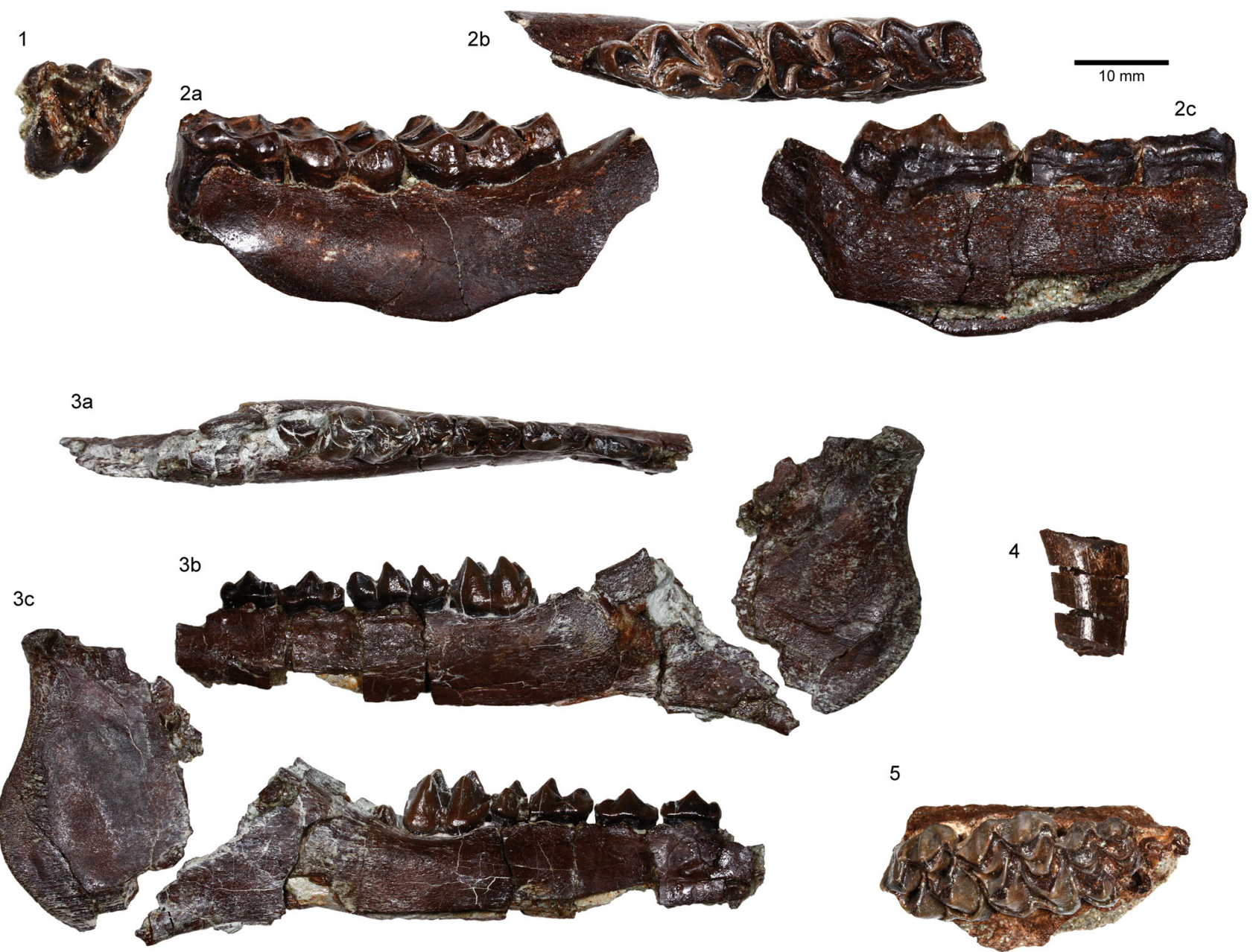

4

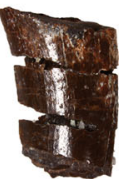

$6 a$

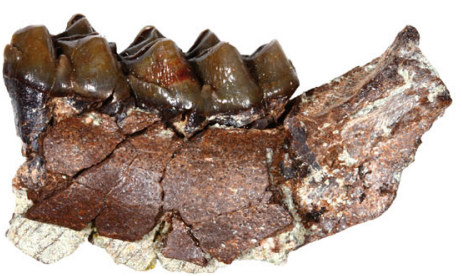

7

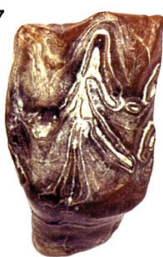

8

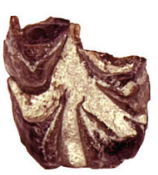

Fig. 3 Cetartiodactyla from Wallenried. Andegameryx andegaviensis. 1 Left D4 (MHNF 31287), occlusal view. 2 Left mandible with m1-3 (MHNF 31286), labial (a), (b) occlusal, and lingual views $(c)$. Friburgomeryx wallenriedensis. 3 Right nearly complete mandible with alveoli of the $\mathrm{d} 2$, the tooth row $\mathrm{d} 3-\mathrm{m} 1$, and $\mathrm{m} 2$ erupting (MHNF 31284), occlusal (a), lingual $(b)$, and labial views $(c)$. 4 Fragmented upper canine (MHNF 28454), lateral view. 5 Partial right maxilla with

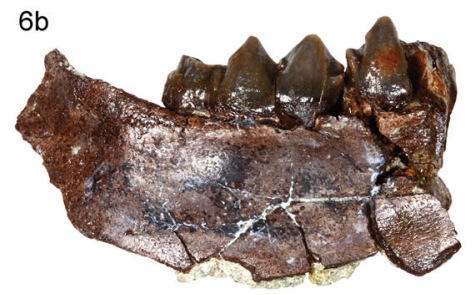

$9 a$

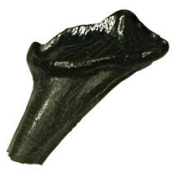

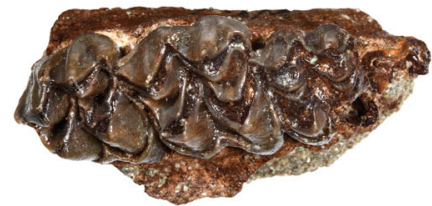

$6 c$

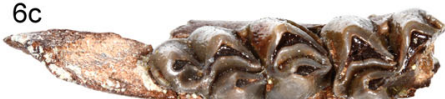

$\overline{10 \mathrm{~mm}}$

$9 b$

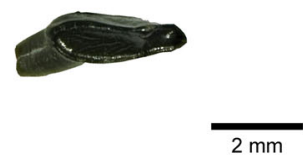

M1-3 moderately to strongly worn (MHNF 28449, Holotype), occlusal view. 6 Left mandible with $\mathrm{m} 2-3$ (MHNF 28452), labial (a), lingual (b), and occlusal views (c). Cainotherium cf. gracile. 7 Worn right M1 (MHNF 31418), occlusal view. 8 Fragmented right M3 (MHNF 31419), occlusal view. 9 Left lower p1 (MHNF 31420), lingual $(a)$, and occlusal views $(b)$. (1-2/2-6/7-9 same scale) 
Table 3 Dental measurements (in mm) of Friburgomeryx wallenriedensis; in each row, the first datum is the length and the second is the width

\begin{tabular}{|c|c|c|c|c|c|c|c|c|c|}
\hline Locality & Inventory number & References & $\mathrm{pl}$ & $\mathrm{p} 2$ & p3 & $\mathrm{p} 4$ & $\mathrm{ml}$ & $\mathrm{m} 2$ & $\mathrm{~m} 3$ \\
\hline \multicolumn{10}{|c|}{ Friburgomeryx wallenriedensis } \\
\hline \multirow[t]{4}{*}{ Wallenried (old locality) } & MHNF 31288 Paratype & Becker et al. (2001) & $7.8 / 3.2$ & $9.8 / 4.9$ & $10.3 / 5.8$ & & & & \\
\hline & MHNF 31282 Paratype & Becker et al. (2001) & & & & & & & $17.3 / 8.5 ?$ \\
\hline & MHNF 31289 & & & & & & & $13.0 ? / 9.5$ & 9.5 \\
\hline & MHNF 28452 & & & & & & & $13.5 ? / 9.3$ & $17.5 / 8.2$ \\
\hline \multirow[t]{2}{*}{ Wallenried (new locality) } & MHNF 31284 & & & & & & $11.5 / 7.2$ & & \\
\hline & MHNF 31285 & & & & & & & $13.5 / 9.3$ & \\
\hline Locality & Inventory number & & $\mathrm{d} 2$ & $\mathrm{~d} 3$ & $\mathrm{~d} 4$ & & & & \\
\hline \multirow[t]{2}{*}{ Wallenried (new locality) } & MHNF 31284 & & $7.6 / 3.2$ & $8.7 / 3.9$ & $13.8 / 5.8$ & & & & \\
\hline & MHNF 31286 & & & & 5.5 & & & & \\
\hline Locality & Inventory number & References & Ml & M2 & M3 & & & & \\
\hline \multirow[t]{2}{*}{ Wallenried (old locality) } & MHNF 28450 Paratype & Becker et al. (2001) & $11.1 / 12.6$ & 12.9 & $12.0 / 13.7$ & & & & \\
\hline & MHNF 28449 Holotype & Becker et al. (2001) & 11.1 & $13.8 / 15.3$ & $12.5 / 14.9$ & & & & \\
\hline
\end{tabular}

vasorum is very enlarged and smooth. The angular process is not prominent. The ramus is slightly reduced. The condylar process is not projected backwards. The coronoid process is relatively short, curved, and highly orientated backwards.

Lower juvenile dentition Only the alveoli of $\mathrm{d} 1$ are preserved. $\mathrm{d} 2$ and $\mathrm{d} 3$ are very similar in shape, but $\mathrm{d} 3$ is larger. They are blade-like. The anterior conid is oblique and ends the tooth. From the central and high mesolabial conid, there is a long anterolabial cristid, ending at the base of the posterolingual conid. The posterior valley is extremely narrow. The posterolabial conids are located on the labial face. The posterolingual conid and the posterior stylid are transverse and form a narrow back valley. On $\mathrm{d} 3$, there is a neocrista in the back valley. $\mathrm{d} 2$ and $\mathrm{d} 3$ do not have cingulid. $\mathrm{d} 4$ is basically of a similar shape to that of the lower molars. However, it possesses relatively low crowns. The anterior stylid is missing. The anterior conid is rounded and surrounded by an anterior cingulid. At its base, there is a large anterior ectostylid. All the lingual cuspids are laterally compressed and aligned in the same axis. The postentocristid is relatively elongated, even if it does not reach the posthypocristid. The latter ends with a well-developed entostylid. The internal postprotocristid and the posthypocristid are transverse, forming a small and acute mesofossa and posterior fossa. The external postprotocristid is missing and the ectostylid is small.

Lower adult dentition The lower molars are relatively bunodont. The internal postprotocristid and the posthypocristid are orientated relatively backwards. On m3, there is a small ridge below the internal postprotocristid that could be the external postprotocristid. However, on the other specimens, it is clearly absent. Even if the lingual cuspids are relatively laterally compressed, they are bulging out on the lingual side. They are aligned and their upper parts are quite sharp. The entoconid is more globular than the metaconid. The postentocristid is long on $\mathrm{m} 1$ and shorter on $\mathrm{m} 2$. It does not fuse with the posthypocristid, forming a gap. The metastyild is small to absent. However, on $\mathrm{m} 2-3$, the mesostylid is prominent, forming a small cingulum. The third lobe of $\mathrm{m} 3$ is relatively simple; only the hypoconulid is present. The orientation of the back fossa of $m 3$ is oblique. The lingual part can possess a very small cristid, the ectostylid is small, and the anterior and the posterior cingulids are relatively large.

Upper adult dentition The upper canine is elongated, large, curved, laterally flattened with an ovoid section. No new upper molars have been found. However, these teeth are characterized by a very strong lingual cingulum, large parastyle, paracone, and mesostyle, and a metaconule reduced only on M3, giving a triangular shape to the tooth.

\section{Discussion}

The new material attributed to Friburgomeryx wallenriedensis shows very primitive features. The cuspids are highly bunomorph, the external postprotocristid is small, the postentocristid is incomplete, and the gap between the entoconid and the posthypocristid is wide. Some of these features (the weak metastylid and rounded metaconid) were already described on MNHF 31287 (Becker et al. 2001, Fig. 4), and the dimensions are similar (Table 3). Moreover, p1 is elongated and in contact with p2, contrary to Andegameryx that shows a diastema between $\mathrm{p} 1$ 
and p2 (Ginsburg and Morales 1989). The presence of an enlarged mesostylid and a huge lingual cingulum on lower molars is relatively uncommon for Agenian ruminants. Quiralte and Morales (2006) described an enlarged Andegameryx sp. (larger than A. laugnacensis and $F$. wallenriedensis; Tables 2 and 3 ) in the Burdigalian of Spain. The latter possesses a big mesostylid; however, the upper molars are without cingulum. Babameryx engesseri from the latest Oligocene of Switzerland is a derived representative of the Pecora possessing a large lingual cingulum on its upper molars (Mennecart et al. 2012; Mennecart and Métais 2014). However, no mesostylid is observed on lower molars and the metaconule on all upper molars is reduced. Becker et al. (2001). Prothero (2007) proposed to ascribe Friburgomeryx to the primitive Moschidae (such as Dremotherium, Amphitragulus). Sanchez et al. (2010) notice in their cladistic analysis a certain amount of moschid autapomorphies: the separation between the foramen ovale and the infratemporal fossa by a low and small crest; the p4 morphology shows the mesolingual conid joining the anterolabial cristid through the posterolingual cristid with strongly developed anterolingual cristid that encloses entirely or almost entirely the anterior valley; the third lobe of the $\mathrm{m} 3$ is bicuspidate, with presence of well developed postentoconulidcristid; the capitular facet in the radius elongated and wide; the metatarsal plantar tuberosity present. The morphologies of the p4 being simple and primitive for the derived Pecora (including the absence of bicuspidate third lobe of m3), we agree with Sanchez et al. (2010) that Friburgomeryx does not belong to Moschidae. This family only appeared in Europe from MN5 onwards (Sanchez and Morales 2008; Sanchez et al. 2010). Primitive hornless ruminants with sabre-canines from the latest Oligocene (MP28) to the Agenian have been attributed to Moschidae for a long time, by convenience (Gentry et al. 1999; Becker et al. 2001; Prothero 2007). However, cranial, dental, and postcranial characteristics do not support this hypothesis. Without further information, all these primitive ruminants are currently defined without familial attribution (Costeur 2011; Mennecart 2012; Scherler et al. 2013; Mennecart and Métais 2014).

\section{Eupecora indet.}

Referred specimens MHNF 31283, two fragments of lower molar.

\section{Description and discussion}

These two small fragments of molars belong to a ruminant smaller than Andegameryx and Friburgomeryx. The presence of enlarged stylids (metastylid or entostylid) confirms that this ruminant can neither be ascribed to Friburgomeryx nor Andegameryx.

\section{Suborder INCERTAE SEDIS \\ Family CAINOTHERIIDAE Cope, 1881 \\ Genus Cainotherium Bravard, 1828 \\ Cainotherium cf. gracile Pomel, 1846}

Fig. 3.7-9

Referred specimens MHNF 31418 worn right first upper molar $(4.7 \times 4.4 \mathrm{~mm})$, MHNF 31419 fragmented right third upper molar $(? \times 3.3 \mathrm{~mm})$, MHNF 31420 left lower first premolar $(3.2 \times 1.3 \mathrm{~mm})$. Measurements are provided in Table 4.

\section{Description and discussion}

This cetartiodactyl is very small. The sole cuspidate p1 only possesses one root. The protoconid is high and very anterior. A basal ridge surrounds its lingual part. The upper molars are selenodont five-cusped teeth, the M1 being rectangular when the M3 is squarer, which is characteristic of the genus Cainotherium. On M1, the postprotoconulidcristid joins the preprotocristid, contrary to the M3, in which those crests are parallel. The paracone is as high as the metacone on M1. The metacone is broken on MHNF 31419. They possess a well-developed secondary crest in the posterior basin.

During the Agenian, the genus Cainotherium is well diversified with at least six species (Heizmann 1999; Berthet 2003; Scherler et al. 2013). The interspecific dental pattern remains quite monotonous, with a large intraspecific variation. Only data based on size on a large population and tooth rows allow a good determination (Berthet 2003). Basically, Berthet (2003) proposed three different size-classes (small: C. gracile, C. geoffroyi, $C$. miocaenicum; medium: C.lintillae; and large: C. commune, C. latircurvatum). Considering the extremely minute size of the specimens from Wallenried, this Cainotherium belongs to a small form and probably to the smallest species Cainotherium gracile (Berthet 2003). 
Order LAGOMORPHA Brandt, 1855

Family OCHOTONIDAE Thomas, 1897

Genus Titanomys Meyer, 1843

\section{Titanomys sp.}

Fig. 4.1-2

Referred specimens and measurements WallA: one left upper molariform (MHNF 31477; L: $1.04 \mathrm{~mm}$ ), one left p3 (MHNF 31478; L: $1.00 \mathrm{~mm}$; W: $1.00 \mathrm{~mm}$ ). WallE: right D3-4 (MHNF32285).

\section{Description}

Both available specimens from WallA are extremely worn, the distance between the occlusal surface and the root being minimal. In the upper molariform, the hyperlophs are broken. The parafossette is long, with an undulated anterior part that covers a round, small mesofossette. The p3 has a bilobed trigonid, indented by an anterior, shallow flexid, and two lateral flexids: the lingual one is relatively deep, whereas the labial one is very shallow. Due to the bad preservation state of the occlusal surface, it is not clear if trigonid and talonid are united in a hourglass shape or if the hypoflexid connects to the opposite lingual flexid.
The upper decidual tooth recovered from WallE is a very worn fragment retaining only the lingual portion. The mesial hyperloph is larger than the distal one. Any further observation is impossible, and due to its small size, this tooth has been tentatively assigned to Titanomys.

\section{Discussion}

The measurements of Titanomys sp. from WallA are about 40-50 \% smaller than average Titanomys visenoviensis of central Europe (Tobien 1974). The bad preservation state of the scanty specimens from WallA and WallE makes their specific attribution impossible.

Genus Prolagus Pomel, 1853

Prolagus aff. praevasconiensis Ringeade, 1979

Fig. 4.3-5

Referred specimens WallA: 3 left P2 (MHNF 31479-31481); 5 right P2 (MHNF 31482-31486); 4 left P3 (MHNF 31487-31490); 1 right P3 (MHNF 31491); 4 left p3 (MHNF

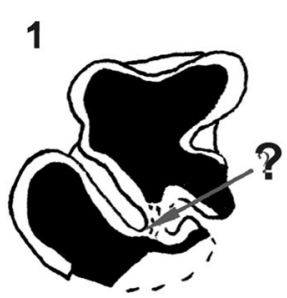

3
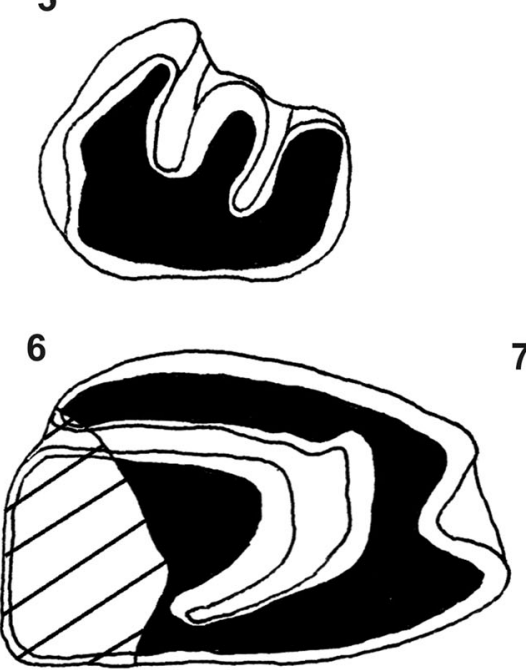

7
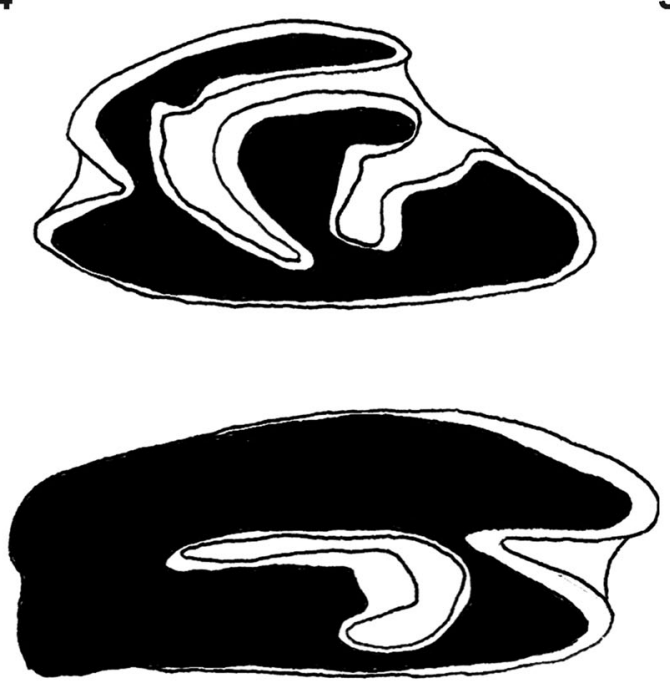

\section{$1 \mathrm{~mm}$}

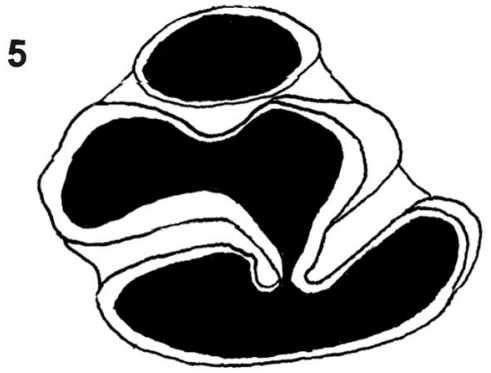

8

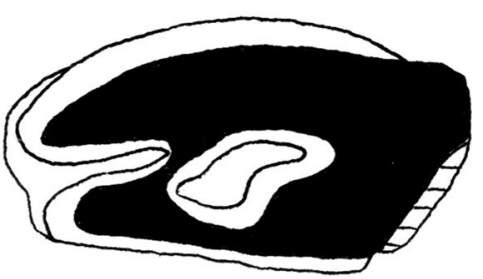

Fig. 4 Lagomorpha from Wallenried. Titanomys sp. 1 Left p3 (MHNF 31478). 2 Left upper molariform (MHNF 31477). Prolagus aff. praevasconiensis. 3 Left P2 (MHNF 31480). 4 Left P3 (MHNF
31489). 5 Right p3 (MHNF 31494). Lagopsis aff. spiracensis. 6 Right P3 (MHNF. 1505). 7 Right M1 (MHNF 31507). 8 Left M2 (MHNF 31508) 
31499-31502), 7 right p3 (MHNF 31492-31498); WallE: left upper molariform (MHNF 32286).

Measurements (min-max range of $\mathrm{L}$ and $\mathrm{W}$, in $\mathrm{mm}$ ) $\mathrm{P} 2$ : $0.63-1.21 \times 0.98-1.58 ;$ P3: $1.27-1.64 \times 2.17-2.42 ; \mathrm{p} 3$ : $1.25-1.71 \times 1.29-1.83$.

\section{Description}

The lobe proportions of $\mathrm{P} 2$ are quite different between worn and unworn individuals. In younger specimens, the three lobes show more or less the same height, thickness and inclination (almost vertical). In older ones, the protocone is enlarged and tends to grow over the metacone; the metacone becomes oblique and tends to overlie the postcone. Unworn individuals show a small additional cusp at the base of the postcone, and in two unworn specimens an additional cusp is present above the postcone; both cusps disappear with wear. In one unworn individual there is also a kind of metaflexus. In unworn specimens, mesoflexus and paraflexus are equally deep, whereas in older specimens, the protoflexus tend to be shorter than the mesoflexus. The enamel band is quite thick, especially in the lingual side.

The P3 has a flattened shape, deep hypoflexus, short mesial hyperloph reaching the half of the centrocone, incipient lagiloph, deep paraflexus and mesoflexus, postcone indented in the anterior lingual part in about $40 \%$ of specimens.

The $\mathrm{p} 3$ possesses a short protolophid always connecting trigonid and talonid. The anteroconid is flat and wide, variable from oval to triangular; in younger individuals, it tends to be more shifted towards the labial side. The centroflexid is deeper in less worn individuals, whereas it is reduced to an undulation in worn ones; the metaconid is middle-sized, is shaped as an elongated oval, and does not show significant intrapopulational variation; the protoconid anterior border is close to the anteroconid; in some cases, the protoconid shows a feeble projection that may become a protoconulid. The protoflexid is long, straight and oriented obliquely; the mesoflexid is $\mathrm{J}$-shaped and indents the internal part of the thick entoconid; in an unworn specimen, a large hypoconulid can be observed.

\section{Discussion}

The population from WallA shows some similarities with $P$. praevasconiensis, reported from zone MN2 of Switzerland (see among others Ringeade 1979), i.e., a similar size range, p3 with protoflexid, and P3 with incipient lagiloph. However, there are some important differences between Prolagus from WallA and $P$. praevasconiensis from the type locality Balizac (see Ringeade 1979, p. 32, Figs. 3, 4; p. 35, Fig. 14). In Prolagus from WallA:

1. In $\mathrm{P} 2$ the protoflexus is quite short.

2. In $\mathrm{P} 2$ the protocone is always very developed in adults.

3. In $\mathrm{p} 3$ the anteroconid is flattened and very large.

As for point 3, Prolagus from WallA is more similar to $P$. tobieni and P. schneitheimensis, which, however, have different upper teeth morphology and different temporal and geographical distributions. Due to its mixed morphological characteristics, Prolagus from WallA is classified herein as Prolagus aff. praevasconiensis.

The sole, broken specimen recovered in Walle does not provide further data.

Genus Lagopsis Schlosser, 1884

Lagopsis aff. spiracensis Baudelot and Crouzel, 1974

Fig. 4.6-8

Referred specimens two left P3 (MHNF 31503-31504); one right $\mathrm{P} 3$ (MHNF 31505); one right M1 (MHNF 31507); one left M2 (MHNF 31508).

Measurements (min-max range of $\mathrm{L}$ and $\mathrm{W}$, in $\mathrm{mm}$ ) $\mathrm{P} 3$ : $1.19-1.38 \times 2.17 ; \mathrm{P} 4: 1.21 \times 2.88 ; \mathrm{M} 1: 1.17 \times 2.79: \mathrm{M} 2:$ $1.08 \times-$.

\section{Description}

The $\mathrm{P} 3$ is a massive tooth, with very long mesial hyperloph entirely covering the postcone. The labial part of the parafossette is straight, indenting the mesial hyperloph at the bending point towards the posterior part of the tooth. The massive postcone is not indented. P4-M1-M2 are very primitive in appearance. They possess a relatively short hypofleus, and the mesial hyperloph is more protrudent than the distal one. The M1 shows a very large, J-shaped fossette and M2 a small, S-shaped fossette.

\section{Discussion}

The morphology of Lagopsis from WallA seems to be much more primitive than the oldest recorded species of the genus, L. spiracensis from the type locality Espira-duConflent, that is reported "not to show archaic features (=fossettes) on upper molariforms" (Baudelot and Crouzel 1974). In Lagopsis from WallA, fossettes are actually developed and present in M1-2. The morphology and measurements of P3 of Lagopsis from WallA resemble those of L. cf. spiracensis from Mèbre 698 (MN2a; Engesser et al. 1993a p. 237, Fig. 10e), but no further 

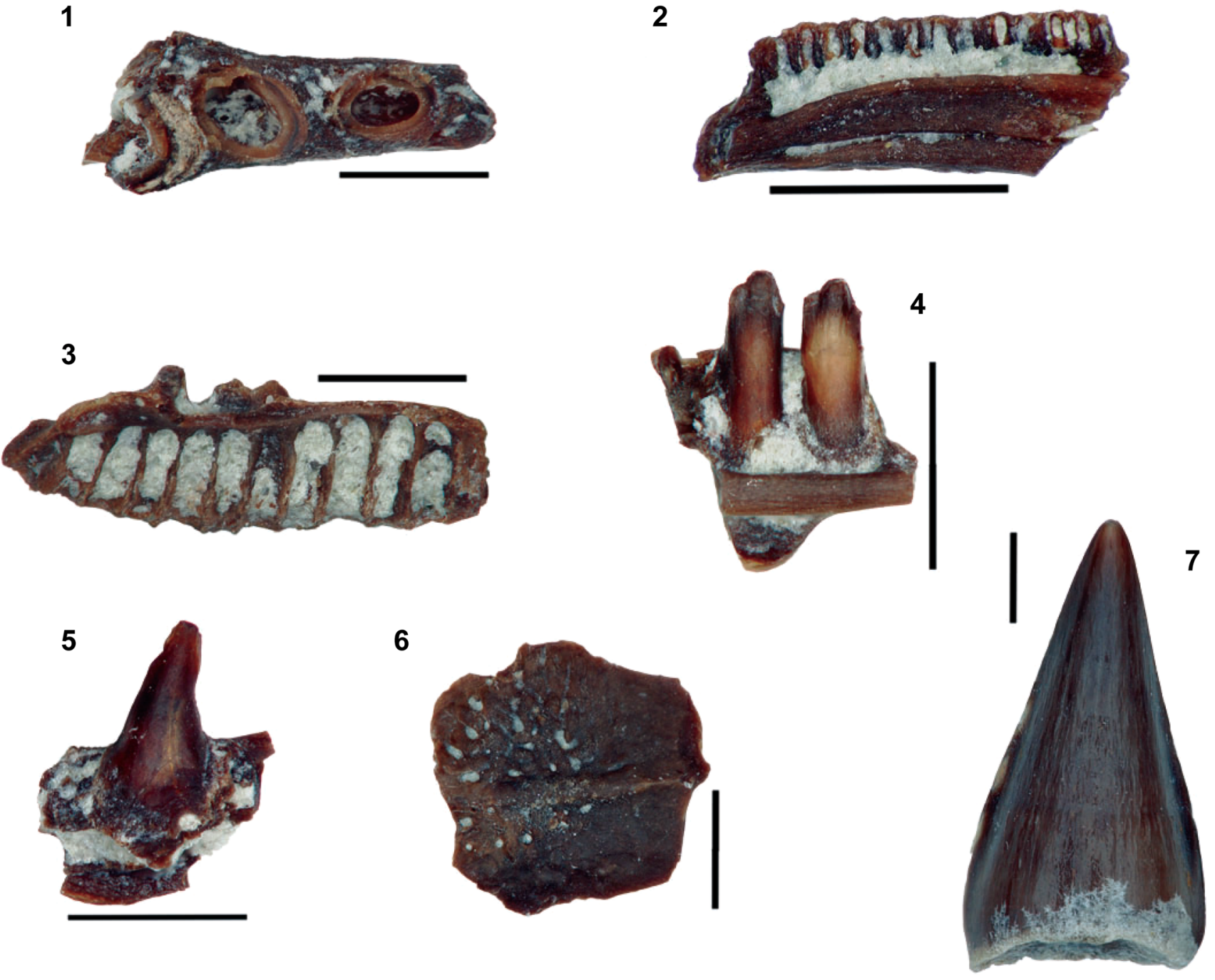

6

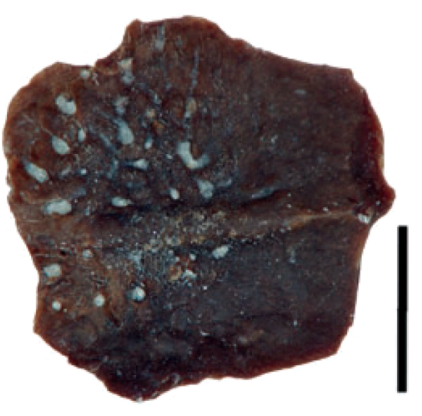

8

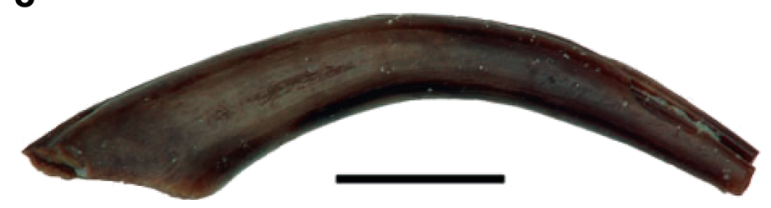

Fig. 5 Actinopterygii, Amphibia, Crocodilia and Squamata from Wallenried A and E (scale $1 \mathrm{~mm}$ for A, C - I; scale $1.7 \mathrm{~mm}$ for B). 1 Gobioninae sp. A (sensu Böhme 2008), anterior fragment of a pharyngeal bone showing a three tooth base (WallA; MHNF 31979). 2 Salamandridae indet., lingual view on fragmentary dental (WallA; MHNF 31980). 3 Anura indet., lingual view of premaxilla (WallA;
9

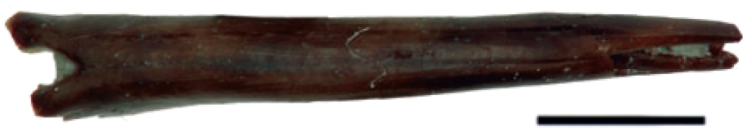

MHNF 31981). 4 Lacertidae indet., lingual view of jaw fragment (WallA; MHNF 31982). 5, 6 Ophisaurus sp., lingual view on jaw fragment (E) and dorsal view on osteoderm (F) (WallA; MHNF 31983-84). 7 Diplocynodon sp., isolate tooth (WallA; MHNF 31985). 8,9 Viperidae, venomous fang tooth (distal point broken) in lateral (H) and mesial (I) view (WallA; MHNF 31986) comparison can be made for lack of material of other cheek teeth. These considerations suggest to classify Lagopsis from WallA as $L$. aff. spiracensis.

No specimens of Lagopsis have been found in the extremely scanty material from WallE.
Class ACTINOPTERYGII Klein, 1882, AMPHIBIA Linnaeus, 1758, CROCODYLIA Owen, 1842 and SQUAMATA Oppel, 1811 from WallA

Fish remains belonging to the family Cyprinidae are represented by abundant isolated (resorbed) pharyngeal teeth 
and a few pharyngeal bones (Fig. 5.1). Pharyngeal tooth morphology reveals the presence of two sub-families: Gobioninae (gudgeons) and Tincinae (tenches). The gobionins are represented by at least two species: a rare largesized gudgeon Gobioninae sp. C (described and figured in Böhme 2008: 164, pl. 1, figs. 4 and 11 from Oberleichtersbach) referred to by Böhme (2008) as cf. Varhostichthys eurystomus (Troschel 1861), and a common smallsized form. Pharyngeal teeth of small-sized gobionins are morphologic identical, but species differ in pharyngeal bone morphology (Böhme 2008). The anterior fragment of a pharyngeal bone from WallA (Fig. 5.1) exhibits a slender anterior process without an anterior angle, therefore resembling Gobioninae sp. A (sensu Böhme 2008: 164, pl. 1, figs. 4, 11) from Oberleichtersbach. Beside the two gudgeons, few paryngeal teeth belong to a tench closely resembling Tarsichthys macrurus (Agassiz 1834), which is also known from Oberleichtersbach (Böhme 2008, pl. 1, figs. 5, 10).

Besides fishes, one fragmentary dental reveals the presence of Salamandridae (Fig. 5.2). Fragmentary cranial remains of anurans are numerous, but postcranials are missing, and therefore a reliable determination is impossible (Fig. 5.3). The same is true for comparatively frequent lizard fragments (Fig. 5.4). Only the common glass lizard (Ophisaurus, Fig. 5.5-6) and the crocodile Diplocyndon (Fig. 5.7) can be determined to the genus level. Most of the 19 crocodile teeth are very small $(<5 \mathrm{~mm})$ and derived from tooth replacement of hatchlings (Böhme 2010). Snakes are recorded by three fragmentary vertebrae of a small sized Colubridae, and by isolate snake fang teeth with an elongate venom discharge orifice (Fig. 5.8-9), which can be assigned to the family Viperidae (Kuch et al. 2006). Venomous fang teeth of vipers from WallA represent one of the oldest records of this group (see "Peculiarities of the Wallenried fossil assemblage").

Order TESTUDINES Linnaeus, 1758

Family TESTUDINIDAE Batsch, 1788

Referred specimens epiplastron (MHNF 31961), fragment of a posterior peripheral (MHNF 31962)

\section{Description}

Quite interesting are two plate fragments of Testudinidae from Channel. The left epiplastron (Fig. 6) of a mediumsized tortoise (total length $30-35 \mathrm{~cm}$ ) is extremely thick shelled (greatest thickness of the epiplastral lip $30 \mathrm{~mm}$ ). The anterior margin of this bone is broken. In visceral view, the epiplastron lip is quite long and flat, but rather

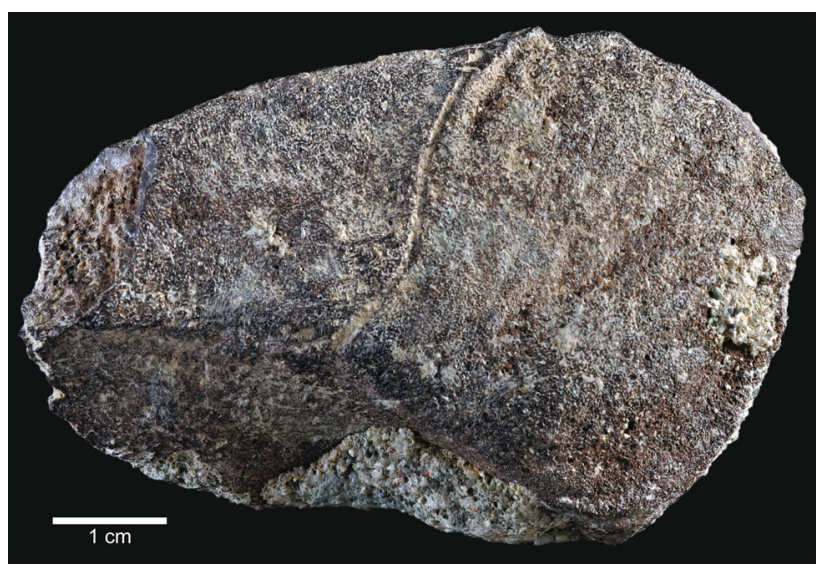

Fig. 6 Ergilemys vel Geochelone, left epiplastron in visceral view (MHNF 31961)

indistinctly developed (no gular pocket). The visceral gular sulci have rising margins (=geochelonid pattern according to Schleich 1988), contrary to Testudo sensu strictu, but likewise to aff. Geochelone described from the Late Oligocene of Oberleichtersbach (Böhme 2008). de Broin (1977) attributes similar tortoises to the Mongolian genus Ergilemys Chkikhvadze 1972, but the phylogenetic relationships to European forms remain unclear. A relation of the Channel tortoise probably exists to the late Oligocene to earliest Miocene western European species "Ergilemys" bruneti (de Broin 1977; Antoine et al. 2006).

Class OSTRACODA Latreille, 1802

Order PODOCOPIDA Sars, 1866

Family ILYOCYPRIDIDAE Kaufmann, 1900

Genus Ilyocypris Brady and Norman, 1989

Ilyocypris essertinesensis Carbonnel, Weidmann, and Berger, 1985

Fig. 7.2-3

Material Two carapaces (WallA); MHNF 31988-89

\section{Discussion}

Size, general shape and ornamentation of our material conforms to the species concept of Ilyocypris essertinesensis in Carbonnel et al. (1985). The tubercle pattern shows a slightly altered, previously unrecorded morphotype of three exclusively dorsal tubercles ("U1 U2 U3"; sensu Carbonnel et al. 1985). The size of this species may vary considerably, regarding locality $(0.77-0.85 \mathrm{~mm}$, probably up to $0.93 \mathrm{~mm}$; see Carbonnel et al. 1985; Picot 2002; Schäfer 2002). Ilycypris essertinesensis occurs in freshwater to slightly brackish Molasse deposits in 
southern Germany, Switzerland and eastern France, and is recorded from the Late Chattian (Carbonnel et al. 1985; Picot 2002), latest Chattian to the earliest Aquitanian (MP29-MN1; Schäfer 2002, 2011) and the Burdigalian (Ottnangian; Reichenbacher 1989; Witt 2000; emended determination of the latter according to Schäfer 2002).

Family CYPRIDIDAE Baird, 1845

Subfamily CYPRICERCINAE McKenzie, 1971

Genus Strandesia Stuhlmann, 1888

cf. Strandesia sp. A

Fig. 7.8

Material Two carapaces (WallA); MHNF 31994 (figured)

\section{Discussion}

Regarding the size, the well-rounded, inflated, only slightly elongated carapace shape with lowly-arched dorsal margin and the relatively blunt dorsal view, our material fits best within the genus Strandesia. It may, however, be confused with selected other members of the Cypricercinae, since the determination is based solely on external morphology (see revisions of the genera in Savatenalinton and Martens 2009a, b). Schäfer (2002) describes comparable specimens from the Brochene Fluh section (Baselland, Switzerland) near the Chattian-Aquitanian boundary as Strandesia sp. A. The material designated as Strandesia sp. from Langhian OSM deposits (Janz 1997a, b) in southern Germany is comparable in size and general shape, but shows a lower, more pointed posterior end.

Subfamily HERPETOCYPRIDINAE Kaufmann, 1900 Genus Psychrodromus Danielopol, and McKenzie, 1977 Psychrodromus aff. olivaceus (Brady and Norman, 1889) Fig. 7.1

Material One left valve, two fragmentary left valves, one fragmentary right valve, four fragments (WallE); MHNF 31987 (figured)

\section{Discussion}

The general characteristics of the genus Psychrodromus as summarized in Martens (2001) apply to our specimens. The scarce, relatively well-preserved material from WallE resembles the Recent Psychrodromus olivaceus in general outline and development of the inner lamella (see e.g., Matzke-Karasz 1995); however, it is distinctly smaller
$(1.43 \times 0.74$ vs. $1.07 \times 0.58 \mathrm{~mm})$. Thus, we do not assume contamination of the samples with recent material. Psychrodromus janzi from the Late Miocene of Slovakia is even smaller (0.83-0.87 mm, left valves) and shows a higher, more rounded lateral profile, whereas $P$. sp. 3 is slightly larger and differs in the shape of the inner lamella (see Pipík and Bodergat 2004). Due to insufficient material, we refrain from a species level determination.

Subfamily EUCYPRIDINAE Bronstein, 1947

Genus MOENOCYPRIS Triebel, 1959

cf. Moenocypris francofurtana Triebel, 1959

cf. M. ingelheimensis Triebel, 1959

Fig. 7.6-7

Material Two carapaces, two fragmentary carapaces (internal moulds; WallA); MHNF 31992-93 (figured)

\section{Discussion}

The diagnostic features of the genus sensu Triebel (1959) are not observable, except for the size, general outline and dorsal view, due to the poor preservation. Both intact carapaces (?moulds) differ in a more bloated, higher form comparable to Moenocypris francofurtana and a slimmer, more elongated shape equivalent to $M$. ingelheimensis (see Triebel 1959). Moenocypris bockenheimensis is morphologically similar to $M$. ingelheimensis, but shows an even more elongated, rectangular lateral outline (Triebel 1963), and is therefore not present in our material. These three taxa are recorded from Chattian (Moenocypris francofurtana, M. ingelheimensis) and Aquitanian (M. bockenheimensis) lacustrine sediments in the northern Upper Rhine Graben (Triebel 1959, 1963). Specimens from an early Aquitanian locality in southern France (Aix Basin) strongly resembling Moenocypris ingelheimensis in size and shape are figured in Reichenbacher (2004). Only fragmentary material has thus far been described from Swiss localities, including La Chaux (MN2a, Aquitanian; USM) and Brochene Fluh (MP29-30, latest Chattian; USM), as Moenocypris sp. (Schäfer 2002, 2005). Moenocypris olmensis from the early Rupelian of the Upper Rhine Graben and the Mainz Basin is shorter and comparably stouter (Triebel 1963; Pirkenseer and Berger 2011).

\section{Additional material}

Eleven carapace moulds from locality WallA may be attributed to the subfamily Cypridopsinae according to their general shape (Fig. 7.5, MHNF 31991). Resembling fossil material is often figured as various, partly open species of 


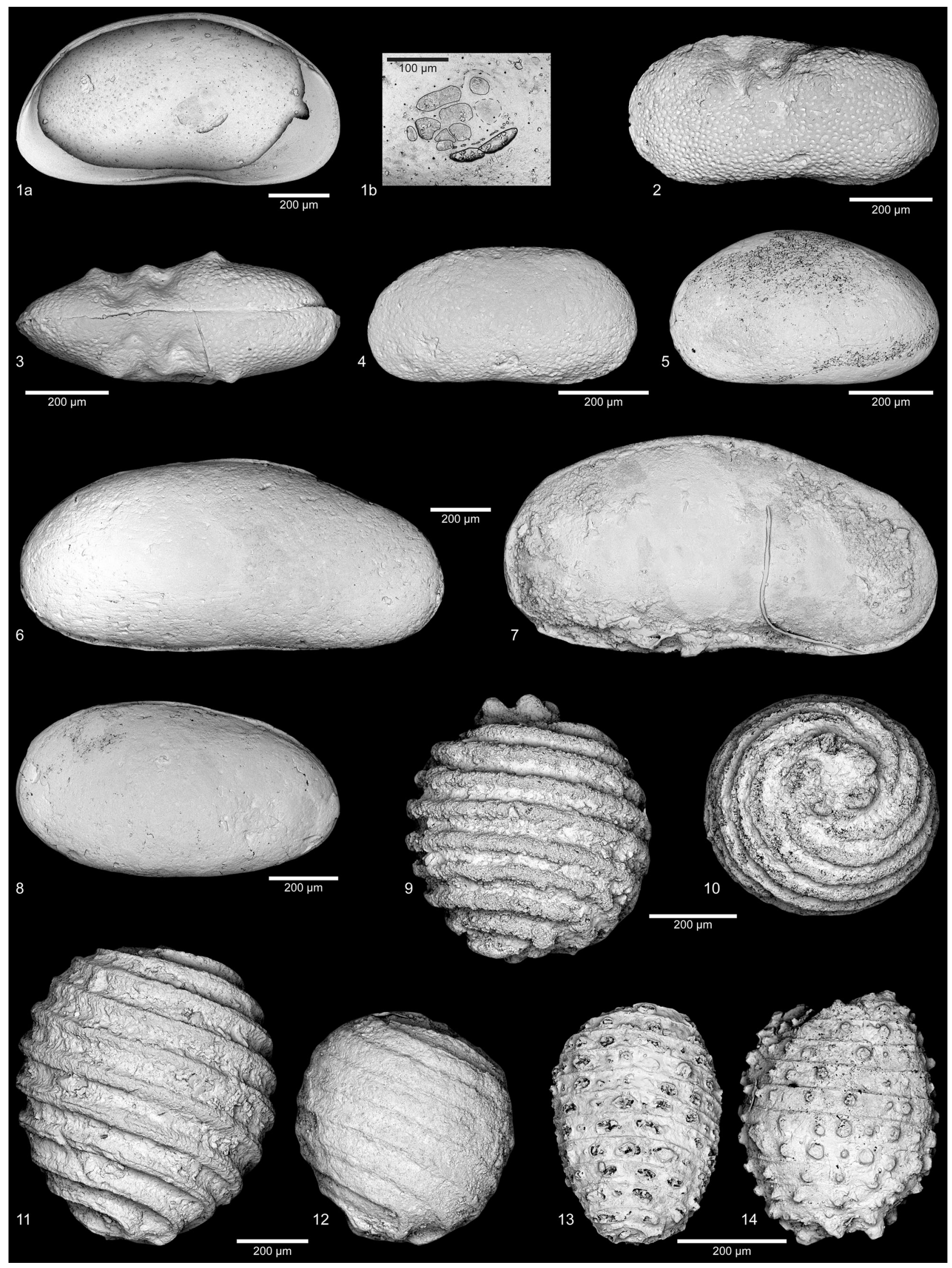


4Fig. 7 Microfossils (2-3/6-7/9-10/11-12/13-14 same scale). 1a, $b$ Psychrodromus aff. olivaceus left valve, interior view (1066 × $583 \mu \mathrm{m}$; WallE; MHNF 31987). 2 Ilyocypris essertinesensis carapace, left lateral view $(767 \times 385$; WallA; MHNF 31988). 3 Ilyocypris essertinesensis carapace, dorsal view $(781 \times 393 \times 290 \mu \mathrm{m}$; WallA; MHNF 31989). 4 Pseudocandona sp. juv. carapace, left lateral view $(595 \times 299 \mu \mathrm{m}$; WallA; MHNF $31990)$. 5 cf. Cypridopsis mould, left lateral view $(643 \times 370 \mu \mathrm{m}$; WallA; MHNF 31991). 6 cf. Moenocypris ingelheimensis mould, right lateral view $(1395 \times 652 \mu \mathrm{m}$; WallA; MHNF 31992). 7 cf. Moenocypris francofurtana ?mould, right lateral view $(1435 \times 731 \mu \mathrm{m}$; WallA; MHNF 31993). 8 cf. Strandesia sp A. mould, left lateral view $(940 \times 514 \mu \mathrm{m}$; WallA; MHNF 31994). 9, 10 Sphaerochara gr. hirmeri, lateral view (9), apical view (10) (MHNF 31995-96). 11 Stephanochara berdotensis, lateral view (MHNF 31997). 12 Stephanochara praeberdotensis, lateral view (MHNF 31998). 13, 14 Chara notata, lateral views (MHNF 31999, 32000)

Cypridopsis from the Paleogene and Neogene of Europe (e.g., Keen 1978; Picot 2002; Gebhardt 2004; Schäfer 2005). However, the size of our material is generally larger than that of the cited taxa, with few exceptions (e.g., $0.73 \mathrm{~mm}$, Cypridopsis sp. in Pipík and Bodergat 2004).

Additionally, one poorly preserved, fragmentary adult carapace and two juvenile carapaces (WallA) belong to the genus Pseudocandona (Fig. 7.4, MHNF 31990).

\section{Charophyta (Characeae)}

Sphaerochara gr. hirmeri (Rasky, 1945) Mädler, 1952

Fig. 7.9-10 (MHNF 31995-96)

\section{Description}

This charophyte is characterized by spheroidal and globulous gyrogonites of small to middle size, with 8-10 concave convolutions and prominent apical cells. This is the most abundant species from Wallenried (several tens of gyrogonites).

Stephanochara berdotensis Feist, 1977 (cf. Feist and Ringeade, 1977) and

Stephanochara gr. praeberdotensis Berger, 1983

Fig. 7.11-12 (MHNF 31997-98)

\section{Description}

Stephanochara berdotensis (Fig. 7.11) and Stephanochara gr. praeberdotensis (Fig. 7.12) are only represented by two specimens of middle size, with double prominent sutures between the spiral cells and a flat or slightly rounded apex. However, the species berdotensis is much larger, with ovoid and slightly elongated gyrogonites showing 7-9 concave spiral cells (Berger 1983). The smaller gyrogonites of St. gr. praeberdotensis are polymorphous (more or less rounded and elongated) with 8-10 convolutions, as well as concave or flat to slightly convex spiral cells (Berger 1983; Berger in Charollais et al. 2007, p. 124).

Chara notata Grambast and Paul, 1965

Fig. 7.13-14 (MHNF 31999, 32000)

\section{Description}

Material of Chara notata is scarce. The small gyrogonites of this typical species show 9-11 slightly concave or convex whorls that bear numerous small tubercles.

\section{Discussion}

\section{Peculiarities of the Wallenried fossil assemblage}

Wallenried is the only known locality of Friburgomeryx (Becker et al. 2001; Prothero 2007).

The lagomorphs from WallA present a unique assemblage. In Switzerland, at the present state of knowledge, Titanomys has never been reported together with Prolagus, nor with Lagopsis.

Another peculiarity represents the confirmation of the oldest record of venomous snake fangs. Although Viperidae are probably known since the Late Oligocene (Böhme 2008), viperid fang teeth were first recorded from the Early Miocene of the Mainz Basin (Kinkelin 1892, Szyndlar and Rage 2002; Kuch et al. 2006). The age of the in-cited inflata beds (now Rüssingen Formation; localities Oppenheim/Nierstein and Hessler-the type locality of 'Provipera boettgeri') can be pinpointed to MN2a (Grimm et al. 2011; contrary to Szyndlar and Rage 2002), equivalent to the supposed age of the Wallenried A deposits (see below).

The Wallenried A fauna contains three species of cyprinid fishes: Tarsichthys macrurus, Gobioninae sp. C (cf. Varhostichthys eurystomus, sensu Böhme 2008), and Gobioninae sp. A (sensu Böhme 2008). All of them are also known from the terminal Oligocene (MP 30) of Oberleichtersbach in Germany (Böhme 2008), thus strongly resembling Late Oligocene freshwater fish faunas from Central Europe, which are characterized by the presence (and often co-occurrence) of gobionin, tincin, and phoxinin cyprinids (Böhme 2007). Although phoxinins (e.g., Palaeorutilus) are missing from Wallenried, these results indicate that the characteristic Oligocene freshwater ichthyofauna survived well into the Early Miocene. 


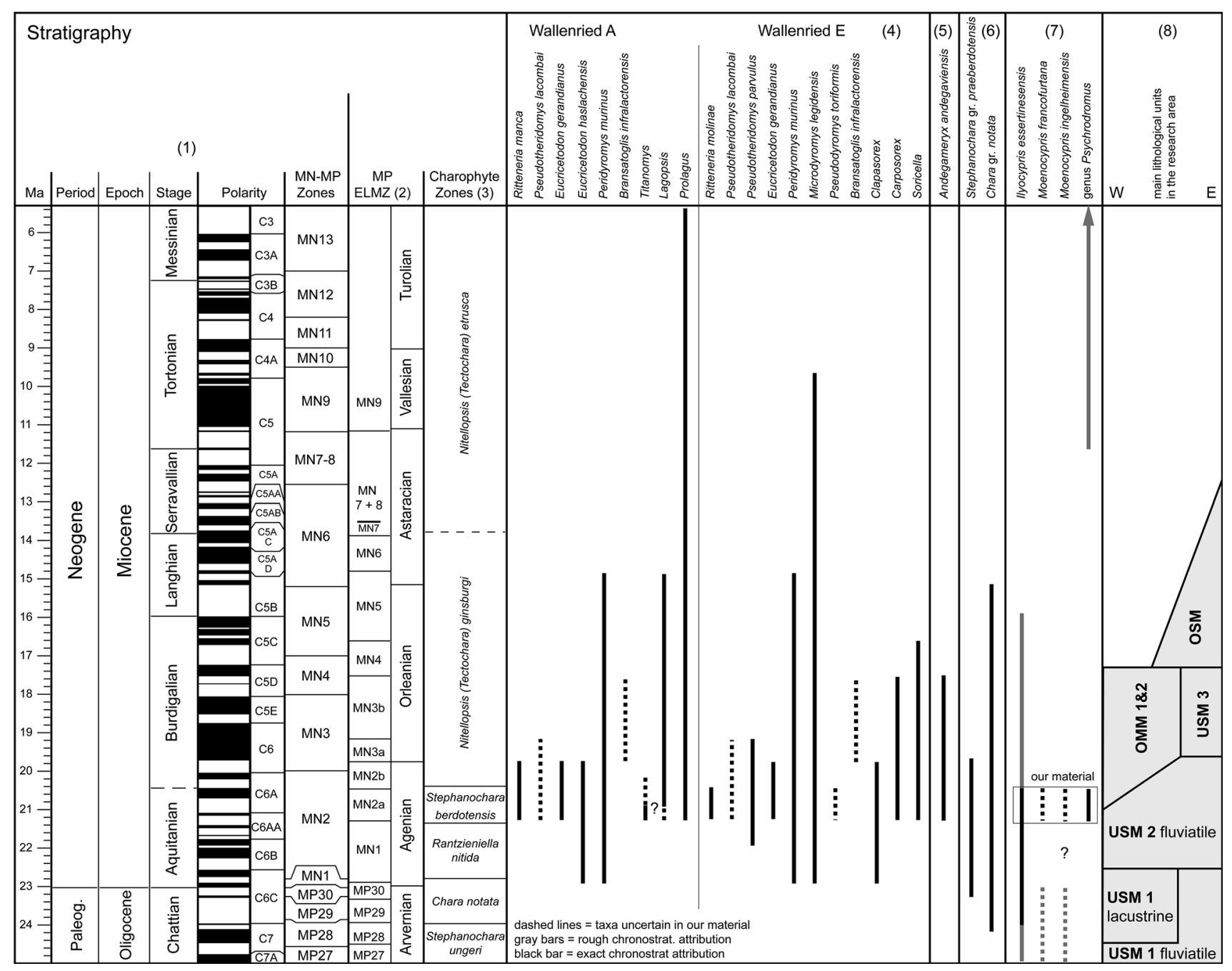

Fig. 8 Stratigraphy. Standard stratigraphy and biostratigraphic ranges of taxa from Wallenried [according to 1 GTS 2012 (built with the time scale creator; https://engineering.purdue.edu/Stratigra phy/tscreator/index/index.php), 2 Steininger (1999), 3, 6 Berger (1999), 4 Boon-Kristkoiz and Kristkoiz (1999), Daams (1999),

The ostracod genus Psychrodromus is described for the first time from Aquitanian sediments. Other fossil Psychrodromus taxa seem to be restricted to upper Miocene or younger deposits (see listing in Pipík and Bodergat 2004), hence making our record the oldest known so far. The other ostracod material conforms to assemblages previously described from Switzerland and the Upper Rhine Graben.

\section{Age of the Wallenried sediments}

The Lower Freshwater Molasse (USM) of Wallenried has yielded four species of Characeae (Sphaerochara gr. hirmeri, Chara notata, Stephanochara berdotensis, and Stephanochara gr. praeberdotensis). In the USM deposits of Western Switzerland, this assemblage of Characeae can be
Engesser (1999), Hugueney (1999), Ziegler (1999), 5 Gentry et al. (1999), Scherler et al. (2013), 7 Triebel (1959, 1963), Carbonnel et al. (1985), Reichenbacher (1989), Schäfer (2002, 2011), Pipík and Bodergat (2004), Reichenbacher (2004), Martens and Savatenalinton (2011), 8 Berger (2011)]

related to the Berdotensis Zone (MN 2a-2b) in the upper part of the Aquitanian Molasse (Berger 1983, 1999; Charollais et al. 2007; see Fig. 8).

The teeth of the three species of ruminants from Wallenried possess very primitive features (e.g., bunoselenodont molars, short postentocristid on lower molars, p1 present, and elongated upper canine). These characteristics are typical of the derived Pecora that are present in Europe between MP28 and MN3 (Mennecart 2012; Mennecart et al. 2012; Scherler et al. 2013; Mennecart and Métais 2014). However, the largest forms occur only in the Miocene. Although Ginsburg (1999) stated that Andegameryx was strictly restricted to MN3, we agree with Gentry et al. (1999) that its record includes the zones MN2a to MN3 (Scherler et al. 2013; see Fig. 8). 
The first records of Prolagus and Lagopsis are from MN2a in Switzerland (Mèbre 698, Engesser et al. 1993a). Lagopsis aff. spiracensis from WallA is more primitive than $L$. cf. spiracensis from Mèbre 698, whereas $P$. aff. praevasconiensis has some features that may be considered advanced compared to $P$. praevasconiensis. The presence of Titanomys further complicates the biochronological framework, as its record is older and usually does not overlap with the records of Prolagus and Lagopsis (BoonKristkoiz and Kristkoiz 1999; López Martínez 2008, p. 34, Fig. 7). The sediments of WallE only contain Prolagus and probably Titanomys. However, the extreme scantiness and bad conservation of the specimens do not allow any biochronological inference.

The rodent assemblage comprises 11 species, of which detailed morphology and size will be presented in a future publication. Nonetheless, the faunal list is very similar to that of La Chaux 7 (Switzerland; Engesser and Mödden 1997) and Ulm-Westtangente (Germany; Costeur et al. 2012), notably by the occurrence of the rodents Ritteneria manca, R. molinae, Peridyromis murinus, Bransatoglis infractolensis ingens, Pseudodryomys cf. toriformis, Eucricetodon gerandianus, Eucricetodon haslachensis. Furthermore, based on the new collected material, the association of Eucricetodon gerandianus, Eucricetodon haslachensis and Ritteneria confirms the correlation with the European biozone MN2 (sensu Mein 1999).

According to Becker et al. (2001) the upper layers at Wallenried are slightly younger than or similar in age to La Chaux 7 and Mèbre 698 based on the genera Eucricetodon and Prolagus, suggesting an age of MN2b at local scale. However, the association of Eucricetodon gerandianus with Ritteneria in both new sample locations (WallA just subjacent to "channel" of Becker et al. 2001) indicates an age close to Les Bergières and La Chaux 7, rather than with La Mèbre 698 (Kälin 1997), then correlating to the local zone MN2a (Engesser 1999; Fig. 8). Contrary to the Ritteneria fossils from WallE, the specimens from WallA are slightly smaller without longitudinal crests, indicating a more derived form in WallA ( $R$. manca) than in WallE ( $R$. molinae). Ritteneria molinae is usually considered as the ancestor of R. manca (Engesser 1990, 1999), which indicates that WallE is slightly older than WallA. Within the Swiss Molasse Basin, the locality of WallA is close in age to La Chaux 7 (assemblage zone of La Chaux 7 sensu Engesser and Mödden 1997), whereas WallE seems to be older and closer to Les Bergières (assemblage zone of Les Bergières sensu Engesser and Mödden 1997).

Despite the differences in the charophyte assemblage and the fact that no cricetid remains were found in the Rüssingen quarry (Mainz Basin, Germany; Engesser et al. 1993b), the association of Pseudotheridomys cf. parvulus, Peridomys murinus and Ritteneria molinae (especially in
Steinbruch Rüssingen 005) also suggests an age close to WallE, and consequently Les Bergières, as already stated by Engesser et al. (1993b).

\section{Paleoenvironment}

The mammal assemblage from Wallenried is relatively diverse with 21 species, and comparable with other Agenian localities in the Swiss Molasse Basin (Engesser and Mödden 1997). The presence of several species of Gliridae indicates the occurrence of wooded and relatively humid areas in the close surroundings (Daams 1999). Talpidae, such as Paratalpa found in WallE, are fossorial animals that live in open areas with humid ground.

The palaeoecological value of the species of European ochotonids and stem lagomorphs has not been defined yet, though in the Middle Miocene of western and central Europe, the relative abundance of Prolagus vs. Lagopsis has been used as an indicator of relative temperature and humidity changes (Lòpez-Martìnez 1977, 1984, 2001; Angelone 2009; Prieto et al. 2009). If applied to the Early Miocene deposits of Wallenried, the higher abundance of Prolagus vs. Lagopsis in WallA would suggest a rather cool and wet environment, which conflicts with the analysis below.

In contrast, in his analysis of postcranial remains of ruminants, based on the method of Köhler (1993), Becker et al. (2001) proposed a subtropical forest habitat, which confirms the humid component but suggests a warmer environment. However, Köhler (1993) does not distinguish between a humid forest and a swampy environment.

According to the synthesis (Picot 2002) of the palaeoecology of freshwater ostracods from the slightly older "Calcaires delémontiens" (MP29 to MN1) Formation the presence of Strandesia, Ilyocypris, Pseudocandona, Moenocypris and Cypridopsis implies a littoral to sublittoral, probably warm and well-oxygenated lacustrine environment for locality WallA. Recent Strandesia show a purely tropical distribution (Martens and Savatenalinton 2011).

However, recent Psychrodromus taxa are restricted to the Palaearctic region (ibid.) in fluviatile and spring habitats (e.g., Pieri et al. 2009; Janz and Matzke-Karasz 2001). Pipík and Bodergat (2004) and Pipík et al. (2012) associate Miocene Psychrodromus with cold freshwater influx into a lake. The unrelated ostracod assemblages indicate different environments for the origin of the material in localities WallA and E. Since the ostracod material in WallA is rather poorly preserved, it may very well be transported over longer distances, whereas the good preservation in WallE suggests an autochthonous deposition or only short transport.

A well-oxygenated lacustrine environment for WallA is also supported by the fish fauna. Recent and fossil 
gobionins are benthic and commonly associated with running water or well-oxygenated bottom waters of lakes (Böhme 2008). Furthermore, the high abundance of isolated (resorbed) pharyngeal teeth supports a lacustrine origin of the sediments (Böhme 2010). In accordance with the numerous, but highly fragmentary, cranial remains of frogs and lizards, an accumulation of small vertebrates by birds of prey on lake margin sediments seems a likely explanation. Alternatively, the highly fragmented cranial remains of frogs resulted from tadpoles, which would explain the lack of well-ossified (and diagnostic for taxonomy) postcranial bones. Shallow littoral lake environments can also be interpreted as a favourite nursery for crocodile hatchlings (Böhme 2010). The climate during deposition of WallA was thus probably quite humid and warm.

This association of various contemporaneous environments including ponds and lakes may be explained by a floodplain in the context of a meandering river system (see Becker et al. 2001 for details on the sedimentary architecture). While the richest fossil level in Becker et al. (2001) relates to the base of a coarse-grained channel infill ("channel") and thus to a clear river influence, both WallA and WallE are located within the fine-grained floodplain marls. At the locality WallE, the dark sediment colour possibly indicates a high organic content and/or oxygen depletion in the water column of a stagnant floodplain pond. Since poorly oxygenated bottom waters inhibit the colonization by benthic ostracods, Walle possibly represents a lentic water body with a steady but minor, cooler freshwater influx supplying Psychrodromus specimens.

Following the cooling event (Pekar et al. 2006) occurring at the base of the Miocene, the simultaneous presence of tropical and palaeartic ostracods in Wallenried, but also the ambiguous signal indicated by vertebrates (as it was also observed for the locality of Ulm-Westtangente, MN2, Costeur et al. 2012), might actually reflect an ongoing change in ostracod and vertebrate communities, inherited from a cooled period and slowly adapting to a warmer climate.

\section{Conclusions}

The new material of two highly fossiliferous levels (WallA and WallE) in the Wallenried quarry and the reassessment of old material from Wallenried provide new information on ruminant taxonomy. Friburgomeryx shows a unique association of features, such as a huge lingual cingulum on upper molars, the presence of an elongated p1, and a large metastylid on lower molars. However, the metaconule is relatively well defined on upper molars, contrary to Babameryx. Without further information, its phylogenetic affinities remain unknown. The reassessment of the specimens of Andegameryx, including new material, permits us to attribute the material to the medium-sized $A$. andegaviensis, instead of the previous determination as the larger A. cf laugnacensis. This implies one of the oldest occurrences of this species.

The charophyte and large mammal assemblages are characteristic of the Agenian. The association of $E u$ cricetodon gerandianus, Eucricetodon haslachensis and Ritteneria confirms the correlation with the European biozone MN2. Furthermore, at a local scale, the presence of Ritteneria species dates the assemblage to MN2a. The faunal compositions of the layers WallA and WallE show differences, which is probably due to small age differences, with WallA (late MN2a, close to La Chaux 7) being younger than WallE (older MN2a, closer to Les Bergières). WallA is characterised by the first and only recorded cooccurrence of the lagomorphs Titanomys, Prolagus and Lagopsis.

The high diversity of fossils, with ectothermic vertebrates (such as venomous snakes), ostracods, charophytes, and at least 21 species of mammals, distinguishes Wallenried as an important locality within the Swiss Molasse Basin. This fossil assemblage suggests a rather open environment with small wooded patches surrounding freshwater bodies, probably small, partly stagnant lakes in the proximity of a meandering river system. Ostracods and mammals provide an ambiguous signal concerning the palaeotemperatures; however, the occurrence of crocodiles excludes that the climate could have been cool.

Acknowledgments We are indebted to André Fasel and Emanuel Gerber (Natural History Museum of Fribourg) for the funding of this project by the Natural History Museum of Fribourg. Our deep gratitude goes to our colleague and friend Prof. Jean-Pierre Berger, who highly contributed to the study of this locality by supervising Bachelor student (Noémie Philipona) and funding a part of the research by the University of Fribourg. Mennecart Bastien received support from the Swiss National Science Foundation (project 200021-115995, 200021-126420, and PBFRP2_145900) and Chiara Angelone received support by the Spanish Ministerio de Economía y Competitividad (CGL2011-28681). We are particularly grateful to Loïc Costeur (Naturhistorisches Museum Basel), Marguerite Hugueney (University of Lyon 1), Damien Becker (Jurassica Museum, Porrentruy), Florent Hiard, and Laureline Scherler, who provided access to collections and helpful discussions. We would like to thank Florent Hiard and Maika Havran for taking images of the mammal remains. Thanks go to the owners and workmen of the Wallenried quarry. We also thank the people who helped us in the field (David Jaramillo, Andrea Strasser, Florent Hiard, Noémie Philipona, Fribourg). Agnes Fatz and Wolfgang Gerber (both Tübingen) provided the images in Figs. 5 and 6.

\section{References}

Angelone, C. 2009. Lagomorphs from the Middle Miocene of Sandelzhausen (southern Germany). Paläontologische Zeitschrift 83: 67-75. 
Angelone, C., and C. Sesé. 2009. New characters for species discrimination within the genus Prolagus (Ochotonidae, Lagomorpha, Mammalia). Journal of Palaeontology 83(1): 80-88.

Antoine, P.-O., F. Duranthon, S. Hervet, and G. Fleury. 2006. Vertébrés de l'Oligocène terminal (MP30) et du Miocène basal (MN1) du métro de Toulouse (SW de la France). Comptes Rendus Palevol 5: 875-884.

Bärmann, E.V., and G.E. Rössner. 2011. Dental nomenclature in Ruminantia: towards a standard terminological framework. Mammalian Biology 76: 762-768.

Baudelot, S., and F. Crouzel. 1974. La faune burdigalienne des gisements d'Espira-du-Conflent (Pyrénées-Orientales). Bulletin de la Société d'histoire Naturelle de Toulouse 110: 311-326.

Becker, D. 1996. Géologie de la region de Cornaux (Jura/NE) et des marnières de Cornaux et Wallenried (USM), 166. Diplôme: l'Université de Fribourg.

Becker, D. 2003. Paléoécologie et paléoclimats de la Molasse du Jura (Oligo-Miocène): apport des Rhinocerotoidea (Mammalia) et des minéraux argileux. Geofocus 9: 1-328.

Becker, D., P.-O. Antoine, B. Engesser, F. Hiard, B. Hostettler, U. Menkveld-Gfeller, B. Mennecart, L. Scherler, and J.-P. Berger. 2010. Late Aquitanian mammals from Engehalde (Molasse Basin, Canton Bern, Switzerland). Annales de Paléontologie 96(3): 95-116.

Becker, D., G.E. Rössner, L. Picot, and J.-P. Berger. 2001. Early Miocene ruminants from Wallenried (USM, Aquitanian/Switzerland): biostratigraphy and paleoecology. Eclogae Geologicae Helvetiae 94(3): 547-564.

Berger, J.-P. 1983. Charophytes de l' Aquitanien de Suisse occidentale. Essai de taxonomie et biostratigraphie. Géobios 16(1): 5-37.

Berger, J.-P. 1985. La transgression de la Molasse marine supérieure (OMM) en Suisse occidentale. Münchner Geowissenschaftliche Abhandlungen 5: 1-204.

Berger, J.-P. 1999. Redefinition of European Oligo-Miocene Charophyte Biozonation. Australian Journal of Botany 47: 283-296.

Berger, J.-P. 2011. Du bassin molassique au fossé rhénan évolution des paléoenvironnements dans un avant pays dynamique. Géochroniques, Magazine des Géosciences 117: 44-49.

Berger, J.-P., B. Reichenbacher, D. Becker, M. Grimm, K. Grimm, L. Picot, A. Storni, C. Pirkenseer, and A. Schaefer. 2005a. EocenePliocene time scale and stratigraphy of the Upper Rhine Graben (URG) and the Swiss Molasse Basin (SMB). International Journal of Earth Sciences 94: 711-731.

Berger, J.-P., B. Reichenbacher, D. Becker, M. Grimm, K. Grimm, L. Picot, A. Storni, C. Pirkenseer, C. Derer, and A. Schaefer. 2005b. Paleogeography of the upper Rhine Graben (URG) and the Swiss Molasse basin (SMB) from Eocene to Pliocene. International Journal of Earth Sciences 94: 697-710.

Berthet, D. 2003. Le genre Cainotherium (Mammalia, Artiodactyla). Étude morphométrique, révision systématique, implications évolutives et paléogéographiques, extinction. Documents $d u$ Laboratoire de Géologie de l'Université de Lyon 159: 1-205.

Böhme, M. 2007. Revision of the cyprinids from the Early Oligocene of the České Středohoři Mountains and the phylogenetic relationships of Protothymallus Laube 1901 (Teleostei, Cyprinidae). Acta Musei Nationalis Pragae B 63: 177-196.

Böhme, M. 2008. Ectothermic vertebrates (Teleostei, Allocaudata, Urodela, Anura, Testudines, Choristodera, Crocodylia, Squamata) from the Upper Oligocene of Oberleichtersbach (Northern Bavaria, Germany). Courier Forschungs-Institut Senckenberg 260: 161-183.

Böhme, M. 2010. Ectothermic vertebrates (Osteichthyes, Allocaudata, Urodela, Anura, Crocodylia, Squamata) from the Miocene of Sandelzhausen (Germany, Bavaria): their implication for environmental reconstruction and palaeoclimate. Paläontologische Zeitschrift 84(1): 3-41.
Boon-Kristkoiz, and Kristkoiz. 1999. Order Lagomorpha. In The Miocene land mammals of Europe, ed. G.E. Rössner, and K. Heissig, 259-262. München: Verlag Dr. Friedrich Pfeil.

Bravard, A. 1828. Monographie du Cainotherium, nouveau genre fossile de la famille des Pachydermes, 35. Paris: Levrault.

de Broin, F. 1977. Contribution à l'étude des Chéloniens. Chéloniens continentaux du Crétacé et du Tertiaire de France. Memoires Musée Nationale Histoire Naturelle C 38: 1-366.

Carbonnel, G., M. Weidmann, and J.-P. Berger. 1985. Les ostracodes lacustres et saumatres de la Molasse de Suisse occidentale. Revue de Paléobiologie 4(2): 215-251.

Charollais, J., M. Weidmann, J.-P. Berger, B. Engesser, J.-F. Hotellier, G. Gorin, B. Reichenbacher, and P. Schäfer. 2007. La Molasse du bassin franco-genevois et son substratum. Archives des Sciences 60(2-3): 59-174.

Cope, E.D. 1881. The systematic arrangement of the order Perissodactyla. Proceedings of the American Philosophical Society 19: 377-401.

Costeur, L. 2011. A partial skull of Dremotherium feignouxi from the Aquitanian of France (MN2, Saint-Gérand-le-Puy, Allier). Acta Geologica Slovaca 3(2): 105-112.

Costeur, L., O. Maridet, S. Peigné, and P.J. Heizmann Elmar. 2012. Palaeoecology and palaeoenvironment of the Aquitanian locality Ulm-Westtangente (MN2, Lower Freshwater Molasse, Germany). Swiss Journal of Palaeontology 131: 183-199.

Daams, R. 1999. Family Gliridae. In The Miocene land mammals of Europe, ed. G.E. Rössner, and K. Heissig, 301-317. München: Verlag Dr. Friedrich Pfeil.

Engesser, B. 1990. Die Eomyidae (Rodentia, Mammalia) der Molasse der Schweiz und Savoyens. Systematik und Biostratigraphie. Schweizerische Paläontologische Abhandlungen 112: 1-144.

Engesser, B. 1999. Family Eomyidae. In The Miocene land mammals of Europe, ed. G.E. Rössner, and K. Heissig, 319-335. München: Verlag Dr. Friedrich Pfeil.

Engesser, B., L. Ginsburg, M. Weidmann, and H. Bucher. 1993a. Les faunes de Mammifères et l'âge de la Molasse grise de Lausanne (Aquitanien). Bulletin de la Société vaudoise des sciences naturelles 321: 209-259.

Engesser, B., and Mödden, C. 1997. A new version of the biozonation of the Lower Freshwater Molasse (Oligocene and Agenian) of Switzerland and Savoy on the basis of fossil Mammals. In Actes du Congrès BiochroM'97, eds. J.-P. Aguilar, S. Legendre, and Michaux, J. Mémoires et Travaux de l'École pratique de HautesÉtudes, Institut de Montpellier 21: 475-499.

Engesser, B., P. Schäfer, J. Schwarz, and H. Tobien. 1993b. Paläontologische Bearbeitung des Grenzbereichs Obere Cerithienschichten/Corbicula-Schichten (= Schichten mit Hydrobia inflata) im Steinbruch Rüssingen mit Bemerkungen zur Oligozän/Miozän-Grenze im Kalktertiär des Mainzer Beckens. Mainzer Geowissenschaftliche Mitteilungen 22: $247-274$

Feist, M., and M. Ringeade. 1977. Etude biostratigraphique et paléobotanique (Charophytes) des formations continentales d'Aquitaine, de l'Eocène supérieur au Miocène inférieur. Bulletin de la Société géologique de France 19(2): 341-354.

Gebhardt, H. 2004. Late Oligocene to Early Miocene foraminifers and ostracods from Karben (Wetterau, Hesse State, Germany): stratigraphic occurrence and palaeoecological implications. Paläontologische Zeitschrift 78: 233-279.

Gentry, A.W., G.E. Rössner, and E.P.J. Heizmann. 1999. Suborder Ruminantia. In The Miocene land mammals of Europe, ed. G.E. Rössner, and K. Heissig, 225-258. München: Verlag Dr. Friedrich Pfeil.

Ginsburg, L. 1971. Un Ruminant nouveau des Faluns miocènes de la Touraine et de l'Anjou. Bulletin du Muséum National d'Histoire Naturelle, Paris 3e série 22: 161-195. 
Ginsburg, L. 1999. Le genre Andegameryx (Artiodactyla, Mammalia). Evolution, position systématique et implications biostratigraphiques. Bulletin de la Société d'Histoire Naturelle, Toulouse 135: 113-117.

Ginsburg, L., and Morales, J. 1989. Les Ruminants du Miocène inférieur de Laugnac (Lot-et-Garonne). Bulletin du Muséum d'Histoire Naturelle, Paris, 4e série, 11, section C, 4: 201-231.

Grambast, L., and P. Paul. 1965. Observations nouvelles sur la flore de charophytes du Stampien du bassin de Paris. Bulletin de la Société géologique de France 7(7): 239-247.

Grimm, K.I., Grimm, M., Radtke, G., Kadolsky, D., Schäfer, P., Franzen, J.L., Schindler, T., and Hottenrott, M. 2011. Mainzer Becken. In Stratigraphie von Deutschland IX. Tertiär, Teil 1, publ. Deutsche Stratigraphische Kommission, Schriftenreihe der Deutschen Gesellschaft für Geowissenschaften, 75: 133-209, Hannover.

Heizmann, E.P.J. 1999. Family Cainotheriidae. In The Miocene land mammals of Europe, ed. G.E. Rössner, and K. Heissig, 217-220. München: Verlag Dr. Friedrich Pfeil.

Hilgen, F.J., L. Lourens, and J. van Dam. 2012. The Neogene period. In A geological time scale, ed. F.M. Gradstein, J.G. Ogg, M. Shmitz, and G. Ogg, 923-978. Amsterdam: Elsevier.

Hugueney, M. 1999. Genera Eucricetodon and Pseudocricetodon. In The Miocene land mammals of Europe, ed. G.E. Rössner, and K. Heissig, 347-358. München: Verlag Dr. Friedrich Pfeil.

Janz, H. 1997a. Die Ostrakoden der kleini-Schichten des miozänen Kratersees von Steinheim am Albuch (Süddeutschland). Stuttgarter Beiträge zur Naturkunde, Serie B 251: 1-101.

Janz, H. 1997b. Über zwei Arten der Gattung Strandesia Stuhlmann 1888 (Ostracoda) aus dem Miozän Süddeutschlands. Geologische Institut der Universität zu Köln, Sonderveröffentlichungen 114: 239-253.

Janz, H., and R. Matzke-Karasz. 2001. Holozäne Ostrakoden aus Karbonatablagerungen im Bereich der neolithischen Feuchtbodensiedlung Unfriedshausen (Bayern) als ökologische Indikatoren. Mitteilungen der Bayerischen Staatssammlung für Paläontologie und historische Geologie 41: 33-63.

Kälin, D. 1997. The mammal zonation of the Upper Marine Molasse of Switzerland reconsidered: a local biozonation of MN 2-MN 5. In Actes du Congrès BiochroM'97, eds. J.-P. Aguilar, S. Legendre, and Michaux, J. Mémoires et Travaux de l'École pratique de Hautes-Études, Institut de Montpellier 21: 515-535.

Keen, M.C. 1978. The Tertiary-Palaeogene. In A stratigraphical index of British Ostracoda, eds. Bate, R.H., and Robinson, E. Geological Journal Special Issue 8: 385-450.

Kempf, O., Bolliger, T., Kälin, D., Engesser, B., and Matter, A. 1997. New magnetostratigraphic calibration of Early to Middle Miocene mammal biozones of the North Alpine foreland basin. In Actes du Congrès BiochroM'97, eds. J.-P. Aguilar, S. Legendre, and J. Michaux. Mémoires et Travaux de l'École pratique de Hautes-Études, Institut de Montpellier 21: 547-561.

Köhler, M. 1993. Skeleton and Habitat of recent and fossil Ruminants. Münchner Geowissenschaftliche Abhandlungen 25: 1-88.

Kuch, U., J. Müller, C. Mödden, and D. Mebs. 2006. Snake fangs from the Lower Miocene of Germany: evolutionary stability of perfect weapons. Naturwissenschaften 93: 84-87.

Linnaeus, C. 1758. Systema naturae per regna tria naturae: secundum classes, ordines, genera, species, cum characteribus, differentiis, synonymis, locis. Holmiae, Impensis Direct. Laurentii Salvii.

Lòpez-Martìnez, N. 1977. Nuevos lagomorphos (Mammalia) del Neogeno y Cuaternario Español. Trabajo sobre Neogeno-Cuaternario 8: 7-15.

López-Martìnez, N. 1984. Los Lagomorfos (Mammalia) de la sucesión del Mioceno inferior de Calamocha (prov. de Teruel). Colóquios de Paleontología 39: 27-44.
López Martínez, N. 1989. Revisión sistemática y biostratigráfica de los Lagomorpha (Mammalia) del Terciario y Cuaternario de España. Memorias del Museo Paleontológico de la Universidad de Zaragoza 3: 1-342.

López-Martìnez, N. 2001. Palaeobiogeographical history of Prolagus, a European ochotonid (Lagomorpha). Lynx (n.s.) 32: $215-231$.

López Martínez, N. 2008. The lagomorph fossil record and the origin of the European rabbit. In Lagomorph biology: evolution, ecology, and conservation, ed. P.C. Alves, N. Ferrand, and K. Hackländer, 27-46. Berlin: Springer.

Mädler, K. 1952. Charophyten aus dem nordwestdeutschen Kimmeridge. Geologisches Jahrbuch 67: 1-46.

Martens, K. 2001. Taxonomy of the Herpetocypridinae (Ostracoda, Cyprididae). Crustaceana 74(3): 295-308.

Martens, K., and S. Savatenalinton. 2011. A subjective checklist of the recent free-living, non-marine Ostracoda (Crustacea). Zootaxa 2855: 1-79.

Matzke-Karasz, R. 1995. Aktuelle Gattungs- und Artmerkmale bei Scottia, Cyclocypris, Psychrodromus und Mesocypris. Geologische Institut der Universität zu Köln, Sonderveröffentlichungen 97: 1-285.

Mein, P. 1999. European Miocene mammal biochronology. In The Miocene land mammals of Europe, ed. G.E. Rössner, and K. Heissig, 25-38. München: Verlag Dr. Friedrich Pfeil.

Mennecart, B. 2012. The Ruminantia (Mammalia, Cetartiodactyla) from the Oligocene to the early Miocene of Western Europe: systematics, palaeoecology and palaeobiogeography. Geofocus 32: $1-263$.

Mennecart, B., and G. Métais. 2014. Mosaicomeryx new gen., a ruminant from the Oligocene of Europe, and the significance of "gelocids". Journal of Systematic Palaeontology 13(7): 581-600. doi:10.1080/14772019.2014.948505.

Mennecart, B., L. Scherler, F. Hiard, D. Becker, and J.-P. Berger. 2012. Large mammals from Rickenbach (Switzerland, Reference-Locality MP29, Late Oligocene): biostratigraphic and paleoenvironmental implications. Swiss Journal of Palaeontology 131: 161-181.

Montgelard, C., F. Catzeflis, and E. Douzery. 1997. Phylogenetic relationships of Artiodactyls and Cetaceans (Mammalia) as deduced from the comparison of cytochrome $\mathrm{b}$ and 12S rRNA mitochondrial sequences. Molecular Biology and Evolution 14: $550-559$.

Pekar, S.F., R.M. DeConto, and D.M. Harwood. 2006. Resovling the late Oligocene conundrum: deep sea warming and Antarctic glaciation. Palaeogeography, Palaeoclimatology, Palaeoecology 231: $29-40$.

Picot, L. 2002. Le Paléogène des synclinaux du Jura et de la bordure sud-rhénane: paléontologie (Ostracodes), paléoécologie, biostratigraphie et paléogéographie. Geofocus 5: 1-240.

Pieri, V., K. Martens, F. Stoch, and G. Rossetti. 2009. Distribution and ecology of non-marine ostracods (Crustacea, Ostracoda) from Friuli Venezia Giulia (NE Italy). Journal of Limnology 68(1): $1-15$.

Pipík, R., and A.-M. Bodergat. 2004. Cyprididae (Ostracoda) du Miocène supérieur du Bassin de Turiec (Slovaquie): taxonomie et Paléoécologie. Revue de Micropaléontologie 47: 225-242.

Pipík, R., A.-M. Bodergat, D. Briot, M. Kováč, J. Král, and G. Zielinski. 2012. Physical and biological properties of the late Miocene, long-lived Turiec Basin, Western Carpathians (Slovakia) and its paleobiotopes. Journal of Paleolimnology 47: 233-249.

Pirkenseer, C., and J.-P. Berger. 2011. Paleogene Ostracoda from the southern Upper Rhine Graben: taxonomy, palaeoecology and palaeobiogeography. Palaeontographica, Abteilung A 295(1): $1-149$. 
Pomel, A. 1846. Note sur des animaux fossils découverts dans le département de l'Allier. Bulletin de la Société géologique de France 2(4): 378-393.

Prieto, J., M. Böhme, H. Maurer, K. Heissig, and H. Abdul-Aziz. 2009. Sedimentology, biostratigraphy and environments of the Untere Fluviatile Serie (Lower and Middle Miocene) in the central part of the North Alpine Foreland Basin-implications for basin evolution. International Journal of Earth Sciences 98: $1776-1791$.

Prothero, D.R. 2007. Family Moschidae. In The evolution of artiodactyls, ed. D.R. Prothero, and S.C. Foss, 189-212. Baltimore: The Johns Hopkins University Press.

Quiralte, V., and J. Morales. 2006. Los Ruminantes (Artiodactyla, Mammalia) del Mioceno inferior de la Encinilla (Colmenar Viejo, Madrid). Estudios Geologicos 62(1): 515-532.

Rasky, K. 1945. Fossile Charophyten Früchte aus Ungarn. Magyar Nemzeti Museum Naturwissenschaftliche Monatshefte 2: 1-75.

Reichenbacher, B. 1989. Feinstratigraphische Gliederung der Kirchberger Schichten (Unter-Miozän) an der Typuslokalität Illerkirchberg bei Ulm. Geologica Bavarica 94: 135-177.

Reichenbacher, B. 2004. A partly endemic euryhaline fish fauna (otoliths, teeth) from the Early Miocene of the Aix-Basin (Provence, southern France). Courrier Forschungs-Institut Senckenberg 246: 113-127.

Ringeade, M. 1979. Découverte de nouveaux Lagomorphes dans le Miocène inférieur d'Aquitanie et implications biostratigraphiques. Bulletin de l'Institut de Géologie du Bassin d'Aquitanie 26: 1-47.

Sanchez, I.M., M.S. Domingo, and J. Morales. 2010. The genus Hispanomeryx (Mammalia, Ruminantia, Moschidae) and its bearing on musk deer phylogeny and systematics. Palaeontology 53(5): 1023-1047.

Sanchez, I.M., and J. Morales. 2008. Micromeryx azanzae sp. nov. (Ruminantia: Moschidae) from the Middle-Upper Miocene of Spain, and the first description of the cranium of Micromeryx. Journal of Vertebrate Paleontology 28(3): 873-885.

Savatenalinton, S., and K. Martens. 2009a. Generic revision of Cypricercinae McKenzie, 1971 (Crustacea, Ostracoda), with the description of three new genera and one new species and a phylogenetic analysis of the subfamily. Hydrobiologia 632: 1-482.

Savatenalinton, S., and K. Martens. 2009b. Redescription of the type species of Strandesia Stuhlmann, 1888 and Cypricercus Sars, 1895 (Crustacea, Ostracoda, Cypricercinae), with a description of a new species of Cypricercus from South Africa. Zootaxa 2007: $1-42$.

Schäfer, P. [with a contribution of Kälin, D.] 2002. Beiträge zur Ostracoden- und Foraminiferen-Fauna der Unteren Süßwassermolasse in der Schweiz und in Savoyen (Frankreich). 1. Das Profil Brochene Fluh (Kanton Baselland, Schweiz). Courrier Forschungs-Institut Senckenberg 237: 193-227.
Schäfer, P. [with contributions of Kalin, D. and Reichenbacher, B.] 2005. Beiträge zur Ostracoden- und Foraminiferen-Fauna der Unteren Süßwassermolasse in der Schweiz und in Savoyen (Frankreich). 2. La Chaux (Kanton Waadt, Schweiz). Senckenbergiana lethaea 85(1): 95-117.

Schäfer, P. 2011. Beiträge zur Ostracoden- und Foraminiferen-Fauna der Unteren Süßwassermolasse in der Schweiz und in Savoyen (Frankreich). 3. Das Findreuse-Profil (Département HauteSavoie, Frankreich). Zitteliana A 51: 255-283.

Scherler, L., B. Mennecart, F. Hiard, and D. Becker. 2013. Evolution of terrestrial hoofed-mammals during the Oligocene-Miocene transition in Europe. Swiss Journal of Geosciences 106: 349-369.

Schleich, H.-H. 1988. Eozäne Schildkrötenreste (Reptilia, Testudines) von St. Pankraz am Haunsberg (Österreich). Studia Geologica Salamanticensia especial 3: 165-184.

Scopoli, J. A. 1777. Introdvctio ad historiam natvralem sistens genera lapidvm, plantarvm, et animalivm hactenvs detecta, caracteribvs essentialibvs donata, in tribvs divisa, svbinde ad leges natvrae. Prag, Wolfgang Gerle.

Steininger, F.F. 1999. Chronostratigraphy, Geochronology and Biochronology of the Miocene "European Land mammal mega-Zones (ELMMZ)" and the Miocene "Mammal-Zones (MN-Zones)". In The Miocene land mammals of Europe, ed. G.E. Rössner, and K. Heissig, 9-24. München: Verlag Dr. Friedrich Pfeil.

Szyndlar, Z., and J.-C. Rage. 2002. The fossil record of the true vipers. In Biology of the vipers, ed. G.W. Schutt, M. Höggren, M.E. Douglas, and H.W. Greene, 419-444. Eagle Mountain: Eagle Mountain Publishing.

Tobien, H. 1974. Zur Gebißstruktur, Systematik und Evolution der Genera Amphilagus und Titanomys (Lagomorpha, Mammalia) aus einigen Vorkommen im jüngeren Tertiär Mittel- und Westeuropas. Mainzer Geowissenschaftliche Mitteilungen 3: 95-214.

Triebel, E. 1959. Moenocypris n.g. (Crust., Ostr.). Senckenbergiana Lethaea 40(1-2): 1-17.

Triebel, E. 1963. Ostracoden aus dem Sannois und jüngeren Schichten des Mainzer Beckens: 1-Cyprididae. Senckenbergiana Lethaea 44(3): 157-207.

Vandenberghe, N., R. Speijer, and F.J. Hilgen. 2012. The Paleogene period. In A geological time scale, ed. F.M. Gradstein, J.G. Ogg, M. Shmitz, and G. Ogg, 855-922. Amsterdam: Elsevier.

Witt, W. 2000. Süßwasserostrakoden der miozänen Vorlandmolasse Süddeutschlands. Mitteilungen der Bayerischen Staatssammlung für Paläontologie und historische Geologie 40: 109-151.

Ziegler, R. 1999. Order Insectivora. In The Miocene land mammals of Europe, ed. G.E. Rössner, and K. Heissig, 53-74. München: Verlag Dr. Friedrich Pfeil. 